\title{
A Natural Wonder: From Linga Mountain to Prosperous Lord at Vat Phu
}

\section{Introduction}

Sanskrit inscriptions are replete with poetic allusions to the monuments commissioned by rulers. While eulogizing King Karkkarāja's temple on Mt. Elāpura, for instance, the poet describes the astonishment of the gods, who are awestruck before the wondrous edifice. Such a temple, they conclude, must be svayambhu, a manifestation of the divine in the landscape, since no human-made construction could inspire such wonder.

\author{
elāpurācalagatādbhutasanniveśam / \\ yad vīkṣya vismitavimānacarāmarendrāh / \\ eta[ $\left.t^{*}\right]$ svayambhu śivadhāma na kṛtrime śrīr \\ dṛstedṛsiti satatam bahu carcayanti // 12 // \\ bhūyas tathāvidhakṛtau vyavasāyahāni[r] \\ etan mayā katham aho krtam ity akasmāt / \\ karttāpi yasya khalu vismayam āpa śilpī \\ tannāmakīttanam akāryyata yena rājñā // 13 //
}

The marvelous excavation in the mountain of Elāpura was commissioned by the king as a monument to his famous name. When they saw it, while cruising by in their celestial chariots, the gods were amazed, saying again and again, "This abode of Siva is a natural wonder; beauty like this is not seen in human constructions." When the work was done, even the artist exclaimed in amazement, "Wow! How did I make this? I could not make such a thing again."1

The genius of the epigraphic description is evident when read in view of the temple itself, a vertical excavation hewn from the living rock.

In another inscription engraved on a monolithic column in Pahari, the poet describes a cohort of deities who, when confronted with the monument, are at a loss to explain its striking perpendicularity. Like the gods at Elāpura, they wonder if the object could be an epiphany.

1 Baroda Copper Plate Inscription of Rāșțrakūṭa Karkkarāja [II] (812 CE); edition by Salomon and translation by author. See Richard Salomon, Indian Epigraphy: A Guide to the Study of Inscriptions in Sanskrit, Prakrit, and other Indo-Aryan Languages (New York: Oxford University Press, 1998), 286.

Ә Open Access. (c) 2021 Elizabeth A. Cecil, published by De Gruyter. (cc) BY-NC-ND This work is licensed under a Creative Commons Attribution-NonCommercial-NoDerivatives 4.0 International License. 
viṣnoḥ kiṃ caraṇas trivikramakṛteḥ stambhākṛter vvā vapuḥ, sthānor bhūvivara[rā]t phan̄indraripuñā śeșo thavā proddhṛtah / ittham bhūri vi[cāra]yadbhir amarair ālokya ni[ścī]yate, stambhaḥ śuddhaśilāmayah parava(ba)la[kṣmā]pālakīrttipradah // 27 //

“Is this Viṣnu's foot making three strides, or the body of the 'Immovable' Siva in the form of a pillar, or the serpent Śeșa pulled out of a hole in the ground by the eagle Garuda, the enemy of the snakes?” Examining it thoroughly, the gods realize that it is, in fact, a column made of bright polished stone, conferring fame upon Parabala, the protector of the earth. $^{2}$

Though artfully executed hyperbole, these verses preserve significant clues about the desired effect of monumental architecture in the Sanskrit imaginary. The monuments described are visually and physically arresting. Even the gods, no doubt accustomed to all sorts of celestial wonders, stop and do a doubletake. The source of this cognitive dissonance is the encounter with something seemingly divine in the mundane world of mortals. By virtue of their other-worldly artistry and scale, the monuments confer "fame" 3 upon their royal sponsors by disguising the work of the human agents who created them. Even the artist from Elāpura experiences his creation as a material "other." As a result, the monuments are initially misapprehended as spontaneous manifestations of divine presence in the natural world. This strategy for cloaking human agency reflects an effort to "naturalize" power, that is, to make the institutions that manifest social dominance and reinforce hierarchical relationships - like royal temples, for example - extensions of a natural order that manifests the very telos of the land. Following this rhetoric, we can conclude that a ruler's ability to transform physical geography (particularly in ways that appeared divine) served as a potent exercise of power. The creation of monuments was an act of political thaumaturgy.

These verses also play on a defining feature of "Hinduism": a religious ecology expressed in the celebration of the natural world and the spiritual magnetism of prominent geographic features. More than just eye-catching landmarks, distinctive mountain peaks, natural springs, rivers, etc. are understood as manifestations of divine presence - called svayambhu (natural or self-existent) deities in

2 Pahari Pillar Inscription of Yuvarājadeva II (861 CE), vs. 27; edition by Kielhorn and translation by author. See L. F. Kielhorn, Epigraphia Indica vol 9 (1907-1908): 248-56.

3 The term kirti, translated as "fame" in both examples above, is, more literally, a "good report." In both passages, the monument is the material trigger for the verbal reports first uttered by the gods. The inscription eternalizes that "good report" in Sanskrit. Finally, as permanent interventions in the landscape, monuments are material triggers for continued verbal exclamations of wonder and admiration over time and, therefore, effect the "conferring of fame" (kirtipradah). 
Sanskrit. The sites of these manifestations are often places of pilgrimage called tìrthas, terrestrial and cosmic "crossings" that confer a multitude of rewards to those people who visit them - ranging from material wealth and physical wellbeing to ultimate beatitude $(m o k s a) .{ }^{4}$ These natural wonders were considered more ritually efficacious than constructed shrines or images because they were spontaneous revelations, and not the work of human hands. The power inherent in svayambhu deities was recognized widely across early South and Southeast Asia. ${ }^{5}$ In the context of premodern Cambodia, these natural wonders were often connected specifically with the God Siva and his iconic emblem, the linga. Perhaps more than any other deity of the Indic pantheon, Siva was adopted and adapted throughout the pre-Angkorian and Angkorian periods to serve as the patron and tutelary deity of aspirational rulers, and the lingas that these rulers installed were the ritual foci of polities and urban centers. The epigraphic and iconographic programs that developed within these monumental spaces aided in publicizing the intimate association between deity, landscape, temple, and ruler.

This study uses landscape as a primary source to show how a religious ecology, in which the physical geography was fully saturated with power and agency, became the basis for the development of a political ecology in which the landscape was similarly understood as a source of empowerment. My definition of "landscape" maps closely onto the Sanskrit word kșetra ("field"). A kṣetra is not only a field for growing crops, but is also used to designate a theater of human and divine activity. Landscape, by this definition, is not simply physical terrain. It is physical terrain designed to serve human aims and ambitions. More specifically, I argue that built interventions designed to claim prominent landscape features served as effective agents of empire because they enabled control of natural places that were widely recognized as sources of divine presence, and they could be used as performative spaces in which that domination could be ritually re-enacted over time.

To explore these hypotheses in detail, the present article traces the development of a foundational political landscape within the nascent Khmer Empire located in what is today southwest Laos. Looking specifically at epigraphic and material evidence, I examine the political claims to and religious investments in a landmark mountain between the fifth century, when the site was first identified

4 On the powers of tìrthas see Diana Eck, "India's Tïrthas: Crossings in Sacred Geography," History of Religions 20, no. 4 (1981): 323-344.

5 On this see also Alexis Sanderson, "Śaiva Religion Among the Khmers (Part 1)," Bulletin de l'Ecole française d'Extrême-Orient 90-91 (2003): 349-462 [410-412]. 
as a svayambhu manifestation of Śiva, through the eleventh century CE, when development culminated in an immense Angkorian-period temple complex known today as Vat Phu. ${ }^{6}$ Exploring what these sources tell us about the divinization of this particular mountain, the cultural agents engaged in the transformation of this landscape feature, and the assumptions about the power of place that informed their practices, has the potential to enrich our conceptions of the historical formation of political geographies in premodern Southeast Asia and beyond.

\section{Old Gods, New Landscapes}

From as early as the fifth century CE, regional mountain landmarks were reimagined as manifestations of Śaiva divinity and invoked as sources of divine empowerment for emerging rulers and polities. Yet while these manifestations of Siva were embedded in local contexts, ${ }^{7}$ a significant number were given names that echoed those of celebrated lingas from Indic mythology and epic political landscapes. The redeployment of these names, and the powerful deities that they invoke, in the context of premodern Cambodia (i.e. the land of the Khmer, Kambujadeśa) has been described by Alexis Sanderson as a "Śaivization of the Land.” A practice designed, in his words, to "transfigure the Khmer realm by creating a Śaiva landscape whose sacred enclaves could be seen as doubles of those of the religion's Indian homeland."

While it is clear that the memory of powerful manifestations of Siva from South Asia informed naming practices and provided an influential conceptual map of sacred geography in many cases, ${ }^{9}$ the language of "doubling" implies a form of mimicry whereby the Khmer religiopolitical landscape was designed to

\footnotetext{
6 This temple complex was one of a number of significant architectural projects, settlements, and hydrological systems undertaken in the greater region. See Michel Lorrillard, "Par-delà Vat Phu. Donées nouvel les sur l'expansion des espaces khmer at môn anciens au Laos," Bulletin de l'Ecole française d'Extrême-Orient 97-98, (2010-2011): 205-270; "Settlement and Spatial Planning around Wat Phu," unpublished paper and slides presented at the 15th EurASEAA conference (accessed via academia.edu on April 1, 2019).

7 The many lingas established within the temples complexes of these polities represented specific, localized instantiations of the ultimate and transcendent deity. Often, they were linked to local rulers as patron deities through the practice of naming lingas after the donative agent followed by the suffix -iśvara. This practice was also common in early South Asia.

8 Sanderson, "Śaiva Religion Among the Khmers," 403.

9 For specific examples and lists, see Sanderson, "Śaiva Religion," 403-409; Peter C. Bisschop, Early Saivism and the Skandapurāna: Sects and Centers (Groningen: Egbert Forsten, 2006), 34-37.
} 
imitate an Indic exemplar. This model offers too straightforward and narrow a description of what was a more complex set of cultural and political processes. Reconsidering the epigraphic sources in the context of the monumental spaces and landscapes in which they functioned indicates that these interventions were part of a larger repertoire of spatial and material practices designed to transform regional geographies into urbanized political landscapes and, in doing so, introduce and enforce an increasingly differentiated and stratified model of social relations. The introduction of Sanskrit toponyms and deities, particularly those linked with a Saiva religious geography, were tools that supported a new social order in which power was concentrated in the figure of the ruler and his affiliates and enacted in imposing monumental complexes situated around important regional landmarks. ${ }^{10}$ The introduction of Sanskrit names and Śaiva titles for local places was not only intended to create an affinity with South Asian sacred geography; India's tïrthas would have been virtually unknown and their titles utterly foreign to all except an initiated few. ${ }^{11}$ This is precisely the point. Śaivism aided in the intentional "othering" of local landscapes for the vast majority and, by doing so, supported the introduction of

10 Paul Wheatley describes this mode of sociopolitical change as "urban generation," a process occasioned in large part by pressures internal to a given society. This remains a useful model, although he relies upon the problematic language of "Indianization" to describe changes in early Cambodia through which indigenous social structures and political units were shaped or replaced by Indic ones. See Paul Wheatley, "Urban Genesis in Mainland Southeast Asia," in Early Southeast Asia: Essays in Archaeology, History, and Historical Geography, eds. R.B. Smith and W. Watson (New York: Oxford University Press, 1979), 288-303. Recent studies have complicated this model to better understand the forms of urbanism that existed in both pre-Angkorian and premodern Southeast Asia. Miriam Stark emphasizes the material aspects of these early cities and the spaces for the performance of power that were integral to their design; see Miriam Stark, "Southeast Asian Urbanism: from early City to Classical State," in The Cambridge World History, vol 3, Early Cities in Comparative Perspective, 4000 BCE-1200 CE, ed. Norman Yoffee (Cambridge: Cambridge University Press, 2015), 74-93. On the development of early cities across Southeast Asia, see John N. Miksic, "Heterogenetic Cities in Premodern Southeast Asia," World Archaeology 32, no. 1 (2000): 106-120.

11 Considering that these toponyms would have been almost entirely unfamiliar or "foreign" in a Southeast Asian context makes the reuse of such names quite different from the phenomena of remapping or reproducing sacred spaces in South Asia. The former is intentionally and strategically alienating, while the latter is designed to promote participation and affinity by encouraging geographic cohesiveness. On practices of reproducing or transposing sacred geographies in South Asia, see Diana Eck, Banaras: City of Light (New York: Columbia University Press, 1982), 283 and Benjamin J. Fleming, "Mapping Sacred Geography in Medieval India: The Case of the Twelve Jyotirlingas,” International Journal of Hindu Studies 13, no. 1 (2009): 51-81. 
new power structures that presided over these ideationally transformed lands. ${ }^{12}$ This is not to imply that the sociopolitical model was necessarily an Indic one; rather, that particular linguistic and cultural forms adapted from Indic contexts and agents provided a means for rulers to control local geographies. ${ }^{13}$ The practices of localization intrinsic to Śaivism ${ }^{14}$ provided a template that allowed ruling elites to claim and control places that were already regarded as powerful, some of them are described enigmatically as the "old gods" in epigraphic sources. Mountains were particular foci of royal interventions, as will be shown below. Importing sacred toponyms and geographies from the Indic world was a tactic that allowed aspiring rulers to claim places of power in the regional landscape and use the "old gods" as bases for the establishment of new political regimes. $^{15}$

The mountain that came to orient the Khmer polity is located in what is today the Champassak district of southwest Laos, a collection of small villages on the bank of the Mekong River over which the distinctive peak of a mountain known locally as Phu Kao presides (Figure 1). The mountain is part of the Dangrek Range, connected with the larger Khorat Plateau, which was an important meeting place

12 It is also important to note that linguistic developments in nomenclature for deities recorded in the Khmer sections of epigraphic texts, particularly from the pre-Angkorian period, also document processes of social change and stratification. See Michael Vickery, Society, Economics and Politics in Pre-Angkor Cambodia: The $7^{\text {th }}$-8th Centuries (Tokyo: The Centre for East Asian Cultural Studies for Unesco, The Toyo Bunko, 1998), 140-151.

13 Important work has been done to show how the introduction of Indic cultural models in Southeast Asia was ideologically and aesthetically driven and catalyzed by Sanskritic registers of artistic and political production - modes of cultural production that created what Sheldon Pollock has termed the "Sanskrit cosmopolis." Yet this rarified world of Sanskrit discourse remains untethered from physical geography and alienated from the very people, places, and polities that it supposedly linked. Also missing from this picture are the infrastructures of social, economic, and gender domination that supported the implementation of elite ambitions on the ground. See Sheldon Pollock, The Language of the Gods in the World of Men: Sanskrit, Culture, and Power in Premodern India (Berkeley: University of California Press, 2006).

14 On the emplaced nature of early Śaivism in South Asia, see Elizabeth A. Cecil, Mapping the Pāśupata Landscape: Narrative, Place, and the Saiva Imaginary in Early Medieval North India (Leiden: Brill, 2020).

15 Julie Estève has drawn attention to this pattern of reinscribing indigenous landscapes through the establishment of Indic deities and the importance of spatial analysis as a tool for charting the development of religious geography in early Cambodia. See Julia Estève, "Mapping the Sacred: Towards a Religious Geography of Ancient Cambodia Through a Toponymic Atlas of Cambodian Inscriptions," in Writing for Eternity: A Survey of Epigraphy in Southeast Asia, ed. Daniel Perret (Paris: EFEO, 2018), 87-108. 


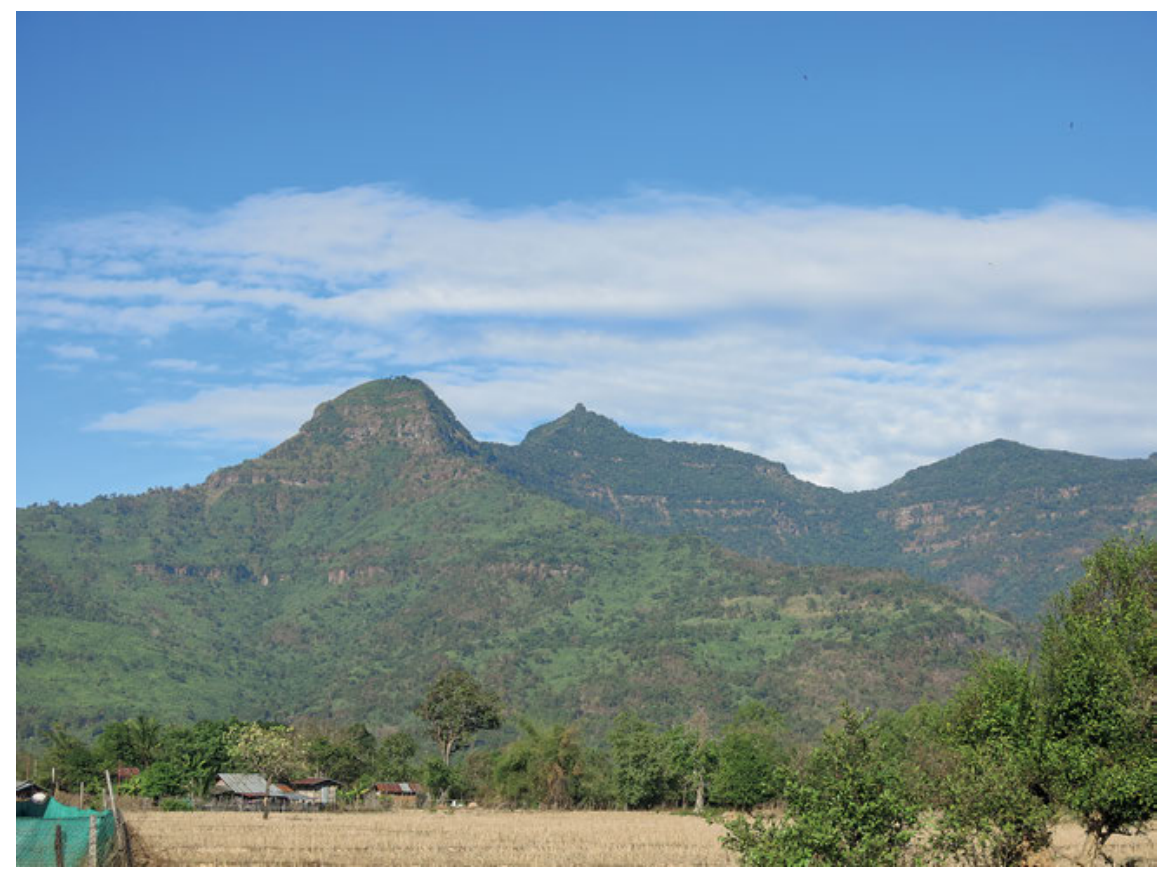

Figure 1: Mt. Phu Kao/ Lingaparvata (author photo).

for overland trade and travel in mainland Southeast Asia. ${ }^{16}$ The significance of this area began in the fifth century and continued in the pre-Angkorian and Angkorian periods when sacred sites and settlements developed along the Mekong River and its many tributaries. The presence of these remains points further to routes that would have linked the Phu Kao mountain region with other sites of transregional significance, specifically Preah Vihar and Sambhor Prei Kuk. ${ }^{17}$ The regional importance of the mountain derives from its two remarkable features: the peak is crowned by a natural stone monolith approximately 60 feet tall, which serves as a landmark for both overland and riverine travel; the second feature is a natural spring that flows from the mountain top and emerges as a small stream from the rocks at its base.

16 Michel Lorrillard, "Pre-Angkorian Communities in the Middle Mekong Valley," in Before Siam: Essays in Art and Archaeology, eds. Nicolas Revire and Stephen A. Murphy (Bangkok: River Books, 2014), 186-215.

17 Lorrillard, "Pre-Angkorian Communities," 194-195. 


\section{Naming the Mountain God}

The political manipulation of this mountain, the spring, and the land surrounding it began in the fifth century, when a Sanskrit inscription reimagined it as a svayambhu deity presiding over a new sacred landscape called Kurukșetra - a reference to the famous Indian tïrtha and site of the Mahäbhärata epic's final battle. This inscription also initiates the transformation of the mountain into the Hindu God Siva. First, through the introduction of the title "Lingaparvata" (Linga Mountain), a name that homologizes the mountain's crowning stone monolith its "characteristic mark," which is the meaning of the term ling $a$ - with the linga of Śiva, which is often represented as a phallic emblem. This Saiva connection is developed further in subsequent inscriptions that identify the deity enshrined on the mountain as Bhadreśvara, the "Prosperous Lord," the five-headed, ten-armed anthropomorphic Śiva whose image, still standing at the base of the mountain, is emblematic of Śaiva Siddhānta, a trans-regional Hindu religious institution. Manifested as the Prosperous Lord, the divine mountain became the tutelary deity of the region's rulers and, eventually, the patron deity of the emergent Khmer empire. The expansive eleventh century terraced temple complex, originally dedicated to Bhadeśvara, still stands at the foot of the mountain, where it is currently dedicated to the Buddha. Today called simply Vat Phu (Temple Mountain), this was the geographic heart and sanctified center from which the Khmer political landscape extended south to, what is today, Cambodia. ${ }^{18}$

\subsection{Ritual and Renewal}

The inception of the political landscape that developed around the mountain is marked by a monumental late-fifth century inscription (K. 365) ${ }^{19}$ found at an ancient settlement site called Vat Luong Kao. The site occupied an area of

18 Michel Lorrillard, "Du centre à la marge: Vat Phu dans les études sur l'espace khmer ancient,” Bulletin de l'Ecole française d'Extrême-Orient 97-98 (2010-2011): 187-204. A number of later K-numbered inscriptions refer back to this heartland in ways that connect the religious and political authority of the Angkorian rulers to their engagement with the sacred mountain and its monumental temple complex. And, as Lorrillard mentions, the road leading from Vat Phu to Angkor was punctuated with monuments, water tanks, and inscriptions that served as an institutional link that materialized this cultural memory and connected the later rulers to the mountain.

19 George Cœdès, "Nouvelles données sur les origines du royaume khmèr: la stèle de Văt Luong Kău près de Văt P’hu,” Bulletin de l'Ecole française d'Extrême-Orient 48, no. 1 (1956): 209-220. 


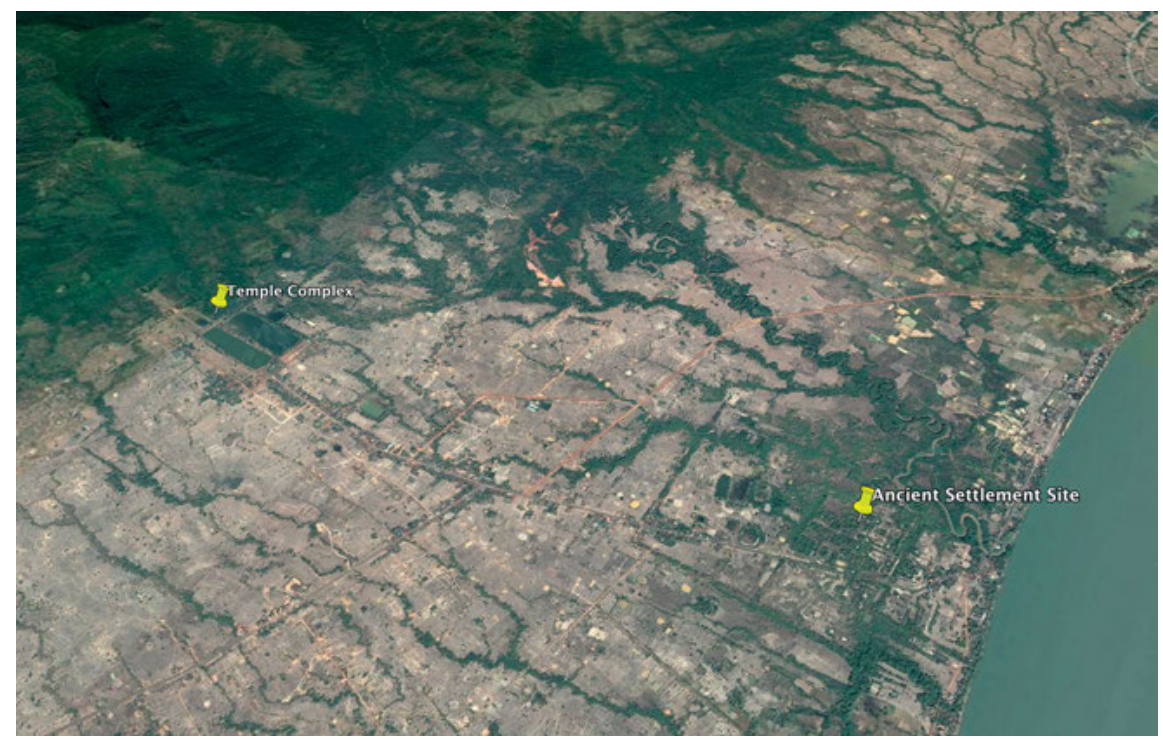

Figure 2: Satellite map showing ancient settlement site (Vat Luong Kao) and temple complex at the base of Lingaparvata (Google Earth).

approximately one square mile on the western bank of the Mekong River (Figure 2). Excavations undertaken in the 1990's by the French Archeological Mission to Laos reported ramparts enclosing numerous foundations of ancient structures, water tanks, levees, and other material remains including a remarkable pre-Angkorian temple lintel, which is now preserved in the Vat Phu site storage. ${ }^{20}$ The inscription was discovered near the confluence of the Mekong and a smaller tributary, the Houay Sa Houa, flowing inland along the northern boundary of the settlement. The text, in Sanskrit language and Brahmi script, is carved on the four faces of a massive (approx. $6 \mathrm{ft}$.) stone stele that resembles a boundary marker used to demarcate sanctified areas (Figure 3). This inscription introduces the mountain as Lingaparvata, a reference to its crowning monolith, and a play on the phallic verticality of that feature. The inscription is remarkable in a number of respects including its early date, knowledge of theological concepts

20 Marille Santoni, Christine Hawixbrock, Viengko Souksavatdy, "La Mission archéologique française et le Vat Phu: recherches sur un site exceptionnel du Laos," in Y. Goudineau et M. Lorrillard (ed.), Recherches nouvelles sur le Laos (Vientiane/Paris: EFEO, coll. "Études thématiques" 18, 2008), 81-111; Marielle Santoni, Christine Hawixbrock, "Laos. Fouilles et prospections dans la région de Vat Phu (province de Champassak, sud du Laos)," Bulletin de l'Ecole française d'Extrême-Orient 85, no. 1 (1998): 387-405. 


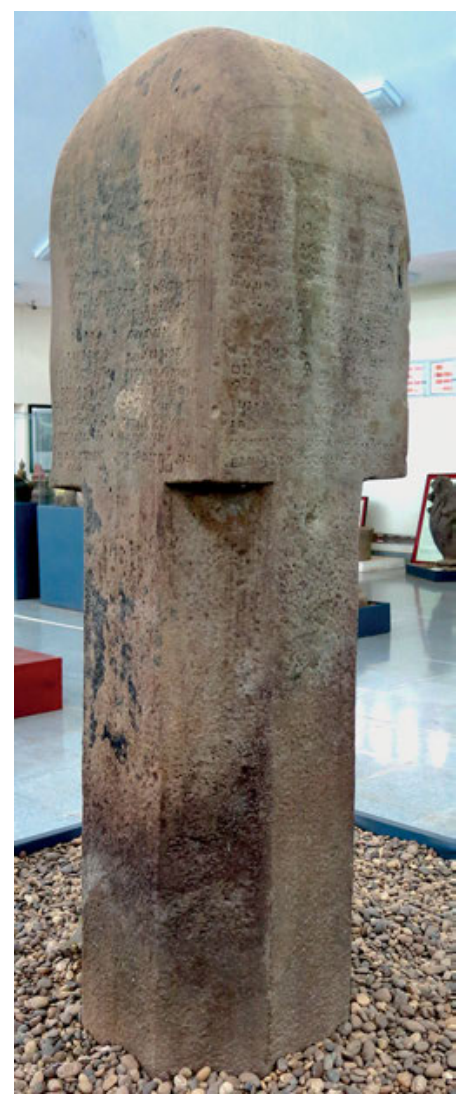

Figure 3: Inscribed stone stele (K. 365), c. fifth century $\mathrm{CE}$, Vat Phu Site Museum (author photo).

current within Brahmanical Hinduism, and familiarity with canonical Sanskrit texts, like the Mahābhārata. ${ }^{21}$ For the purposes of this study, I emphasize the significance of the inscription for the history of the regional landscape. The Sanskrit title initiates a larger process of transformation that situated this regional landmark within a "Hindu" landscape by claiming it as a natural (svayambhu) manifestation of Śiva.

The agent behind this inscription is Devānika - described as "the great king of kings, the illustrious Śrī Devānīka” in the epigraph. In constructing the persona of this king, Devānīka's (presumably Brahmin) poet portrays him as anointed by the gods themselves (Śiva, Viṣnu, and Brahmā) and models him on

21 The connections between this inscription and the Mahābhārata have been studied by Claude Jacques, “Notes sur l'Inscription de la Stèle de Vat Luong Kau,” Journal Asiatique 250, no. 2 (1962): 249-256. 
the heroes of the Sanskrit epic, the Mahābhärata. Yet this movement toward a construction of an idealized and universal sovereignty is grounded within a particular geographic context. We are told that King Devānīka came from a distant country (dūradeśāt) and obtained royal power by the grace of the venerable Śrī Lingaparvata.

(12) . . p pūrvamatena bhagavatā śrīlingaparvvatenāsmin dūradeśād ā(13)nītādhișthito mahādhirājyaiśvaryye viśișțavispașțāșțārddhākșara(14)mañgalanāmadheyo dviṣadanekānīkāvāptavijayo vijaya iva (15) mahārājādhirājaś śrīmāñ chrīdevānīkaḥ

. . . The great king of kings, the illustrious Śrī Devānīka - whose name, clear and distinguished, is comprised of an auspicious set of four syllables; (who) like Arjuna is victorious over numerous enemy armies - brought from a distant land, he was established in this position of supreme Lordship by the "Old God,” the venerable Śrī Lingaparvata . . . ${ }^{22}$

Previous studies have taken this reference to a distant land literally and attempted to determine King Devānīka's ancestry and place of origin; Cœdès links him with the kingdom of Champa, while Jacques suggests the early settlement at Si Thep in Thailand. ${ }^{23}$ I suggest that we interpret the reference to the "faraway land" as a rhetorical device that styled Devānīka as the figure of the "stranger king” explored by Graeber and Sahlins in their recent study on the institution of kingship. ${ }^{24}$ In this interpretation, the distance is not alienating; rather, it gestures to a kind of universality that provides a needed distinction between the ruler claiming power and the people and region he claims to rule. ${ }^{25}$ Devānīka's superior "otherness" is indicated in other ways as well, by his affinity to the gods and

22 This and subsequent passages from K. 365 are reproduced from the edition of Coedès. The translations are my own.

23 George Cœdès, "La stèle de Văt Luong Kău,” 212-213; Claude Jacques and Philippe Lafond, The Khmer Empire: Cities and Sanctuaries Fifth to Thirteenth Centuries (Bangkok: River Books, 2007), 68-69.

24 We could compare this with the tradition of Indic kings being descended from the sun, moon, or from epic heroes in a way that is similarly distancing.

25 As they explain, "Native rulers assume the identity and sovereignty of exalted kings from elsewhere and thus become foreigners - as in the Indic kingdoms of Southeast Asia - rather than foreigners becoming native rulers. The polity is in any case dual: divided between rulers who are foreign by nature - perpetually so, as a necessary condition of their authority - and the underlying autochthonous people, who are the 'owners' of the country. The dual constitution is constantly reproduced in narrative and ritual, even as it is continuously enacted in the differential functions, talents, and powers of the ruling aristocracy and the native people [. . .] The hero manifests a nature above, beyond, and greater than the people he is destined to rule - hence his power to do so.” See David Graeber and Marshall Sahlins, On Kings (Chicago: University of Chicago Press, 2017), 5. 
heroes of Indic literature and theology, ${ }^{26}$ and by his deeds that distinguish him as "superhuman" (atimānuṣakarmman). ${ }^{27}$

Devānīka's spatial distance (expressed by dūra) from the area he claimed to rule is countered in the inscription by an affiliation with the mountain, the area's venerable geographic feature, which is described as pūrvamata (ancient). ${ }^{28}$ The term (or variants of) pūrvamata has been noted by Michael Vickery in his study of Khmer inscriptions as a way to refer to localized deities that are integrated within the Hindu pantheon (typically as forms of Viṣnu or Śiva). ${ }^{29}$ Analyzing patterns of nomenclature in both Sanskrit and Khmer, Vickery argues that the introduction of Indic deities did not constitute a "new religion" per se, but reflected the politically motivated adoption of Sanskrit terms to

26 (5) ity evāyam śrīsanikaranārāyanapitāmahādisarvvadeva(6)prasādābhiṣiktahpūrvvenārjijitaśubhakuśalanimittasaṃbhā (7) vitasarvvakarmmātimānuṣakarmmā yudhișțira iva saddharmmasthitau (8) [vivu]dhanarapatir iva prajāpālane dhanañjaya iva ripugaṇa (9) vijaye indradyumna iva bhūriyajñavidhāne śibir iva dāne mahā(10)dāne bhagavanmahāpuruṣabrahmanyatānucārīva brāhmanyabhāve (1 1) kanakapāṇdya iva nyāyarakṣaṇe mahodadhir iva gāmbhīryye merur iva (12) sthairyye

“. . . Anointed by the grace of all the gods, beginning with Śiva, Viṣnu, and Brahmā. Whose deeds are superhuman since all his actions are resplendent, as a result of the good and auspicious state of his previous birth. Dedicated to the norms of the good like Yudhișthira; like the Lord of the Gods in protecting the people; like Dhanamjaya (Arjuna) in defeating troops of enemies; like Indradyumna in the performance of extensive sacrifices; like Sibi in the donation of great gifts; in his disposition to the rank of Brahmin(s), he is like a follower of the piety of the blessed mahāpuruṣa (Viṣnu); who protects according to rule like Kanakapāṇḍya[?]; (he who is) deep like the ocean (and) like Mt. Meru in stability."

27 Wolters also observed that these descriptions of Devānīka style him as an ideal warrior and king in the "Hindu" tradition, or what he terms a "Hindu" man of prowess. It is also important to note, however, that this self-fashioning is enacted in the highly rhetorical context of a public Sanskrit inscription and we should not assume, as Wolters does, that these are necessarily expressions of personal devotion or piety. See O.W. Wolters, “A 'Hindu' Man of Prowess," in History, Culture, and Region in Southeast Asian Perspectives, rev. ed. (Ithaca, NY: Cornell Southeast Asia Program Publications, 1999), 226-228.

28 The language of distancing and superseding (ati/pūrva) is also evident in the line that praises the king's super-human qualities as a result of positive deeds in previous births (see above).

29 It is possible that the designation of pürvamata could refer to a specific classification of local deities. Michael Vickery surveys a number of early K.-numbered inscriptions in which "old" deities are mentioned and associated with deities like Viṣnu, Siva or the Buddha. Although the precise terminology used differs, the idea of local deities being elevated or transformed through their integration into the Hindu tradition is not uncommon and merits further consideration in this case. See Vickery, Pre-Angkor Cambodia, 139-149. 
characterize familiar tutelary deities and powerful spirits that defined the indigenous religious landscape. ${ }^{30}$ So, while the new ruler pays deference to the old mountain deity, he does so with a new, Sanskrit appellation that works to transform the local landmark into the emblem of Siva and, in doing so, the sanctified center of a new political territory. This change in name also serves to integrate the mountain into the sphere of Saiva ritual and devotional practice. The object, understood as a manifestation of the Lord, was ritually lustrated and garlanded. In both text and image, great emphasis is placed on the efficacy of these rites, the necessity of their proper performance (typically by initiated religious specialists), and the manifold rewards that Siva offered his devotees from quotidian benefits like health, well-being, and fertility, to the fortune, power, and military prowess desired by rulers.

In addition to expressing Devānīka's ties to the regional landscape, the inscription makes a second, significant geographic claim. The area in which Devānīka is making his political investment is designated the "new Kurukșetra" referring to the sanctified landscape par excellence in the canon of Brahmanical Hinduism. The establishment of this locale is described as a ritual event undertaken for the welfare and well-being of the nascent polity (the term used for this is kuśalavidhi). The history and nature of this rite are obscure since we lack other

30 Looking specifically at changes in the use of terms like vrah kamratāin añ ta acas and vrah kanmin kurun añ (and related variants) to describe "old" and "young" deities, respectively, through the adaption of the honorific title vrah kamratān $a \tilde{n}$ used to refer to Indic deities, Vickery presents evidence that these titles were used to refer to local deities often associated with particular places or natural features of the landscape, while also being named in inscriptions as the principal deities honored by religious foundations. Some of these deities likely correspond with neak $t \bar{a} /$ nak $t \bar{a}$, guardian spirits that are still worshipped in contemporary Southeast Asia. Sanskrit terms were introduced to echo these Khmer terms. Vickery mentions bhagavān pürvah and vrddheśvara as ways of expressing the indigenous concept of the "old god" in Sanskrit language. Claude Jacques has discussed the honorific title kamraten jagat and argued that this is not an adaptation of an Indic concept, but a term used to refer to local protective deities or lineage deities with an affinity to nak tā. See Vickery, Pre-Angkor Cambodia, 139-149; Claude Jacques, “The Kamraten Jagat in Ancient Cambodia,” in Indus Valley to Mekong Delta: Explorations in Epigraphy, ed. Noboru Karashima (Madras: New Era Publications, 1985), 269-286. The links between indigenous religious geographies and Indic sacred landscapes are discussed by Paul Mus in the context of Champa, where he also emphasizes the divinization of landscape features in ways that parallel the Khmer examples; see Paul Mus, "Cultes indiens et indigènes au Champa,” Bulletin de l'Ecole française d'Extrême-Orient 33 (1933): 367-410. This topic is also addressed briefly by Stephen A. Murphy and H. Leedom Lefferts, "Adoption of Buddhism and Brahmanism," in The Routledge Handbook of Archaeology and Globalization, ed. Tamar Hodos (London: Routledge, 2017), 768-789, 783. On neak tā, see Alain Forest, Le culte des génies protecteurs au Cambodge: Analyse et traduction d'un corpus de textes sur les neak ta (Paris: L'Harmattan, 1992). 
references or descriptions other than this unique case. From the descriptions offered in the inscription, the central act is that of a solemn pronouncement made by Devānika to sanctify a particular region in his realm. Significantly, the language used to describe this place is not that of a political center, but a place of pilgrimage (tìrtha). More specifically, we are told that he fashions a "new Kurukșetra" along the bank of the Mekong and invokes one of the holiest sites in Indic cultural geography, one celebrated in the Mahābhärata epic, to colonize a new space. We are first told in general terms what the ruler has done.

saṃvarddhanam mahāpāpapāvanaṃ mahātīrttham. ñ cakāra (9)

He established [this] great tirtha which effects prosperity and the purification of serious wrongdoings.

In Sanskrit, a tirtha marks a point of crossing both terrestrial and cosmic. Typically oriented around remarkable features - a river confluence, mountain, etc. - tìrthas are destinations for pilgrimage that confer salvific rewards on human visitors. The findspot of the inscription at the confluence of two rivers conforms to the geographic parameters of a tirtha, and adds further support to the king's claims to rule by divine favor. Devānīka, and/or his Brahmin agents, are well-aware of the importance of Kurukșetra as a tirtha and quote a number of verses from the Mahābhārata to praise it. They may have also been aware of the connection between this tirtha and the office of kingship. In the epic, the archetypical ruler Kuru performed austerities at Kurukșetra and these acts catalyzed the salvific potential of the land. ${ }^{31}$

The act of sanctifying a new space is integral to the kuśalavidhi that the inscription commemorates and is expressed as the foundational pious pronouncement (ädipranidhih) of the king.

yan mayopārijitapunyam ya[[c ca] $]^{32}$ deve[śo]tthitam /

tad evāst $[u]_{-}{ }_{-}$_ tìrtthani_U_phalam // $4 / /$

Let that merit, which has been acquired by me and which derives from the Lord of Gods $\ldots$. be the fruit . . o of the tirtha!

ye vasanti mahātīrthe tatra ca ye mrtā narāh /

snavanam ye ca kurvvanti tatphalam prāpnuvantu te // 5 //

Let those who dwell at the great tìrtha, those who die there, and those who bathe [there], obtain this fruit!

31 Mahābhārata 1.89.43.

32 The conjectures of Cœdès are marked in the text with single square brackets. My additional conjectures, based on contextual readings, are marked with double square brackets. 
yat tat puṇyopamaphalạ̣ prabhāsādipurākṛteh /

- - nāma tad evātra bhavatu dhrtam adya me // 6 //

Let this fruit, which is equal to merit of those deeds undertaken earlier at Prabhāsa and other (tìrthas), certainly come to be held by me here today!

ye devā yajñabhāgārttha[m ā] Igatā rohitā divi /

brahmopendreśvarādyās te tan nāma pradiśantu vai // 7 //

Let the Gods who have come for the sake of a share in the sacrifice [and who] ascend to heaven, Brahmā, Viṣnu, Śiva, and the others, apportion that [fruit], indeed!

[itye]vam ādipraṇidhī rājñ̃āc cintayas tadā /

nāmagataṃ kurukșetra[[ṃ pratișthā]]]pya phalais samam // 8 //

This is the foundational pious pronouncement of the king, thinking thus at that time when he had established [the tìrtha] named Kurukșetra, equal in merit:

yat pūrvvābhihitaṃ svarggyaṃ phalaṃ devarșikīrttitam /

[kurukșe]tre tad evāstu kurukṣetre navotthite // 9 //

Let that fruit earlier declared as leading to heaven and praised by the divine sages at Kurukșetra be at the newly arisen Kurukșetra!

rșinịā kuruṇā pūrvvam [[dharma]]kṣetrīkṛtaṃ satāṃ /

tasmād iti kurukṣetraṃ khyātaṃ tīrtthaṃ mahāphalam // 10 //

Earlier, by the sage Kuru, it was made into the Field of Dharma of the Good. Therefore, it is called Kurukșetra, the greatly rewarding tïrtha.

kurukṣetraṃ gamișyāmi kurukṣetre vasāmy aham /

ye vasanti kurukșetre te vasanti triviștape // 11 //

I will go to Kurukșetra; I will remain in Kurukșetra.

Those people who dwell in Kurukșetra dwell in the highest of the three heavens. ${ }^{33}$

This inscription is extremely rich in important details about the mapping of political and religious landscapes and my presentation is far from exhaustive. For the purpose of this study, there are two central points to make. The first concerns the demarcation of a new political geography through the imposition of Indic topographic markers. Here we see the "Sanskrit cosmopolis" at work in specifically grounded and locally inflected ways. The venerable old god of the mountain is transformed into an emblem of Śiva through a public act of (re)naming that alters its official identity. The emblem of the new polity is accompanied

33 Mahābhärata 3.81.175cd-176ab, but with the order of the two lines reversed. 
by the (re)establishment of another venerable old landmark, the mahätirtha hailed as the "new Kurukșetra." While both instances involve the importation of Sanskrit titles and Indic models to transform local geographies, these transformations operate in distinct ways. The introduction of Lingaparvata introduces a new Sanskrit title (i.e. one that is not known from Indic sources) to claim an existent locale and venerable feature of the regional landscape. The imposition of Kurukșetra as the name of Devānīka's ritually established tìrtha actively creates a new sacred geography where one had not previously existed. Taken together, these two interventions in the local geography are intended to establish and promote the power of the ruler and support a model for a place-based kingship that participates in, yet transforms, Indic models in an effort to colonize new spaces.

While the text of the inscription proclaims the pious effort to transfer the sanctity of the South Asian epic Kurukșetra to a local point of "crossing," the stone object that bears this text communicates a different message. The shape of the stone echoes a traditional boundary marker, but on a much grander scale. ${ }^{34}$ It is a monumental reflex of this familiar object. The imposition of this boundary initiates a process of transformation of a vernacular landscape into a boundaried geography and, I argue, the center of a political landscape. Covered with a Sanskrit inscription on all four faces, the object is the material linchpin for the ideological claims it publicizes. It is the stake in the ground that anchors the canopy of a universal sacred and political geography in the here and now. At the same time, the object also recalls the shape of the ling $a$ and makes material reference to the mountain deity from which Devānīka derives his political authority. Although I would not argue that the object was intended as a linga - in the strict sense of a ritually installed object of worship - I do suggest that the monument was designed in such a way as to call forth both the boundary stone and the devotional icon in material form. ${ }^{35}$

34 This hypothesis may be supported further by evidence that suggests that the Vat Luong Kao stele was not an isolated object. Michel Lorrillard has reported that another monumental stele of nearly identical shape and proportions was excavated nearby. This inscription, cataloged as K477, is severely damaged and has not yet been studied. See Michel Lorrillard, "Research on the Inscriptions in Laos," in Writing for Eternity: A Survey of Epigraphy in Southeast Asia, ed. Daniel Perret (Paris: EFEO, 2018), 87-108.

35 The possibility that the inscription was designed with a linga-like shape was also observed by John Guy, although I think he goes too far in then designating the object as an "inscribed linga." This judgement appears to be based on Cœè̀s's report that the object had a "tripartite structure" with a square base, octagonal section, and crowning round section. This structure 


\section{Linked Geographies: Lingaparvata and Lingapura}

In the late-fifth century inscription of Devānīka, we are introduced to two toponyms: the mountain Lingaparvata and the tīrtha of Kurukșetra. Inscriptions from the seventh century add new layers to the epigraphic stratigraphy of the landscape through geographic references that attest both to the intensified use of Saivism as a language of political power, as well as to the prestige accorded to Lingaparvata and its surroundings within a developing transregional religious and political geography. Inscriptions of this period also utilize a new toponym, Lingapura, in reference to a settlement or administrative zone that appears closely tied to Lingaparvata. ${ }^{36}$ The following discussion focuses on two seventh-century examples.

\subsection{The Śivapāda Mountain}

One set of inscriptions is preserved at a site called Prasat Neak Buos, located along the Dangrek mountain range that flanks the modern Thai-Cambodia border. Although a considerable distance southwest (approx. 125 miles) of Lingaparvata, these locales were linked through systems of overland routes. It seems these routes also served as conduits for the spread of memories and practices that echo those of the Devānika inscription and suggest that the sanctified space at Lingaparvata served as a kind of exemplar. A pair of fragmentary inscriptions in Sanskrit verse and Old Khmer (K. 341), dated 589 and 622 Śaka/673 CE and 699 $\mathrm{CE}$, respectively, are important in this regard since they suggest practices aimed

would seem to suggest the form of a linga; however, the object on display in the Vat Phu site museum lacks the square base that Guy reports. To describe the inscribed object as linga-like is justified and was perhaps intended, but describing the object as an "inscribed linga" suggests a formal ritual function that cannot responsibly be inferred from the evidence. See John Guy, "Tamil Merchants and the Hindu-Buddhist Diaspora," in Early Interactions between South and Southeast Asia. Reflections on Cross-Cultural Exchange, eds. Pierre-Yves Manguin, A. Mani, and Geoff Wade (Singapore: ISEAS Publishing, 2011), 243-262.

36 As Santoni, Hawixbrock, and Souksavatdy comment, it is plausible that Lingapura was the name of the settlement where the Vat Luong Kao stele was found, although there is no clear epigraphic evidence to prove this association. See Santoni, Hawixbrock, and Souksavatdy, "La Mission archéologique française et le Vat Phu.” 
at mapping a Saiva religious geography on a local landscape in ways that recall key aspects of the Devānìka inscription. ${ }^{37}$

The opening ślokas refer to a mountain on which the Lord Siva (as the "Immovable") was manifest through a pair of footprints (pada). The mountain on which this occurred is known as Śivapāda. ${ }^{38}$

yatra sthānumatā sthānan ḍִ́syamānaṃ padadvyaṃ

sthi $\underline{\mathrm{U}} \underline{\mathrm{U}}$ durggayātasya $\underline{\mathrm{U}} \mathrm{U}$ nāma prakāśyate // 1 //

tenāgraśivapādākhyo bhavīṣyan teșu bhūdharạ̣

upāsya $\underline{\mathrm{U}}_{\mathrm{U}}{ }_{-}$U U smaratām api pāvana(/m) //2 //

yatraiva pivatān் same divyasarga U_dhruvam

U U U U U U U U U U U ti viśrutah // 3 //

Given the fragmentary nature of the text, I will summarize rather than attempt to translate the verses. The landscape feature in question is, again, a mountain and a

37 George Cœdès, Inscriptions du Cambodge vol. 6 (Hanoi: Ecole française d'Extrême-Orient, 1937-1966), 23-26. There has been some debate about the reading of the dates for the inscriptions on the northern and southern doorframes. I follow the dating provided by Cœdès.

38 Much has been written on the veneration of footprints in the Indic and Khmer contexts. See, in particular Sachchidanand Sahai, Shivapada in Khmer Art: Rediscovering Angkor in the Footprints of Shiva (Bangkok: White Lotus, 2011); John Guy, "Shiva's Land: Brahmanical Sculpture in the Religious Landscape of Early Southeast Asia," Orientations 45, no. 3 (2014): 50-57. It is interesting to note that the praise of Śivapāda seems to be aware of and echo certain Indic examples. For example, in the early Skandapurāna, the authors celebrate a particular āyatana of Siva located on a peak of Himavat called Mahālaya. It was on Mahālaya Mountain that Śiva placed his footprints and, by virtue of that act, the locale is considered to be a preeminent salvific space (mahatkșetra). So great is the power of this place that even the intent to visit it is sufficient to release a person from prior sins. See Peter Bisschop, Sects and Centers, SP 167.28-36:
saṃsiddhā munayaś caiva ye ca yogiśvarā bhuvi /
samabhyarcya haraṃ bhaktyā tad avāptāḥ paraṃ padam // 29 //
yatra sākșān mahādevo nyastavān padam ātmanah /
yam praṇamya narāh sarve mucyante sarvakilbiṣaị // 30 //
dehabhedam samāsādya yatra tatra yathā tathā /
na punar jāyate jantur yātaḥ siddhim anuttamām // 31 //
tasya saṃkalpanād eva drakșyāmīti mahālayam /
karmabhir mucyate jantur mahāpātakasaṃjñitaih // 34 //

As reported by Alexander Cunningham, there is a site in Bihar called Rudramahālaya where a pair of Śiva's footprints are worshipped. Rudramahālaya is also used as the name of a linga, seemingly inspired by the Indic locale, in two pre-Angkorian inscriptions of the seventh century (K. 493 and K. 109), although neither of these inscriptions refer to the worship of footprints. 
specific place where two footprints were manifested by the agency of Śiva (Sthāṇu). The author of the inscription is adept at homologizing this particular mountain to Lord Siva through the use of the term sthânumat (sthānumat): this reference to an entity that effects "immovability" or "motionlessness" is well suited to describing the mountain (i.e. the bhüdhara; "supporter of the earth") while also invoking a familiar epithet of Siva. That the immovable Lord was manifest at this mountain suggests, as was observed at Lingaparvata, a svayambhu manifestation - that is, rather than a human agent, the deity is the agent behind this manifestation. Padas $c$ and $d$ of the first verse suggest that these footprints were difficult to access and, perhaps because of that, they were known by a particular name (U U nāma prakāśyate). The two syllables preceding the "nāma" are missing, but we could perhaps supply "agra" (foremost; prominent) which is used to characterize the mountain provided in the following verse. It is also interesting to note that Coedés suggests we understand the reference to agraśivapāda in the Sanskrit inscription as synonymous with the expression śivapāda pūrva that appears in later Khmer inscriptions, where it is used to designate the "eastern" Sivapāda. ${ }^{39}$ This may be, but the use of agra (as foremost, first, or prominent) could also imply a temporal primacy, in the sense of something supremely ancient or old, that recalls the use of purvamata in the description of Lingaparvata in K. 365. Perhaps Sivapāda, too, was an old god of the indigenous landscape undergoing a renaissance as a svayambhu manifestation of Siva and the center of an emergent political landscape.

In addition to proclaiming the mountain's new name and Saiva affiliation, the second verse tells us that for those who have performed worship, presumably of the mountain marked by the footprints, it is purifying even for those who merely call it to mind. This description recalls a similar description of the power of Siva's footprints in the early Skandapurāna (see note 38). Finally, the third verse suggests that, in addition to the venerable footprints, there was also a body of water, perhaps conceived of as a tìrtha, on the mountain. ${ }^{40}$ The first half of the verse promises something fixed (dhruvam) in divine heaven for those who drink this water. If we supply "padam" (place; position) to qualify dhruvam

39 Cœdès, Inscriptions du Cambodge 6, 25 fn. 2.

40 In his discussion of pada worship in India, Hans Bakker mentions that these mountain-top shrines often had sacred lakes associated with them. These lakes are understood as hollows made by the footstep of the deity and that subsequently filled with water. While Bakker's analysis focuses on Viṣnupada sites, it is plausible that similar practices were observed in the worship of Śiva's footprints. Hans Bakker, “The Footprints of the Lord,” in Devotion Divine: Bhakti Traditions from the Regions of India, Studies in Honor of Charlotte Vaudeville, eds. Diana L. Eck and François Mallinson (Groningen: Egbert Forsten/EFEO Paris, 1991), 19-37. 
we can understand that those people who drink the water there obtain a fixed place in divine heaven. ${ }^{41}$

The Khmer part of the inscription provides further details about the religious installations and practices at Śivapāda Mountain, including a reference to the king's order to a religious specialist that he should "offer worship $(p \bar{u} j \bar{a})$ to the deity as done at Lingapura and to install there a linga of gold." 42 Subsequent lines delineate a measure of land that extends east up to the boundary of Lingapura and repeat the injunction that pūjā at Mt. Sivapāda should be done as in Lingapura. Contemporaneous epigraphic references, along with those of later sources, indicate that Lingapura was a settlement area and administrative zone in the vicinity of Lingaparvata. ${ }^{43}$ With the recommendation that worship at Śivapāda emulate that at Lingapura, K. 341 offers further evidence that Lingaparvata provided a model for sanctifying a political landscape.

\subsection{Remembering Lingaparvata at Iśānapura}

The second seventh-century inscription that is relevant to this discussion comes from the site of Sambhor Prei Kuk, the ancient pre-Angkorian capital of İsānapura that was founded by İsānavarman (c. 616-635) in the first half of the seventh century. The Saiva affiliation of the polity is clear from its name (i.e. the reference to Îsāna as an epithet of Śiva) and other inscriptions found at the

41 Such a construction would certainly fit the context; the poet's play on the idea of stability and fixity, and the centrality of "pada" understood both as the mark of the presence of Siva and the ability of that powerful presence to elevate devotees to a higher place (pada). This idea of obtaining a fixed or permanent place echoes verse 58 (in M.R. Kale's edition) of the Meghadūta which celebrates a Himalayan locale where the footprint of Siva is worshipped. People who worship the footprints obtain a "sthiraganapada" (the stable position of being a gana).

42 In Cœdès's edition, Lingapurvva and Lingapura are both attested. He understands -pura for both. The term pūrvva, however, is also used in descriptions of Śivapāda as explained above.

43 The earliest reference to Lingapura as an area affiliated with Lingaparvata comes from an inscription (mid-to-late seventh century) carved on the side of a cliff along a waterfall called Phou Pae, located behind the Vat Phu temple complex. Inventoried as K. 1059, the inscription is currently blocked by fallen rock, but a pamphlet by David Bazin of the Vat Phu World Heritage Office records that it praises officials serving in the court of Bhavavarman II and Jayavarman I, particularly one who was the overseer (svāmi) of Lingapura. A number of later inscriptions mention Lingapura in the context of Lingaparvata. For example, the 12th century K. 1297 records a donation made to the "great Śambhu (Śiva) of Lingapura" (lingapuramahāśambhu) with a reference to the mountain's defining linga. See also Claude Jacques, "Two notes on Vat Phou," published online http://www.vatphou-champassak.com/index.php/publications/scientific-publications\#cjac ques. Accessed May, 2020. 
surviving temples and gateways. One of the earliest of these, K. 440, has been dated to the period of İsānavarman's reign and records the installation of a golden linga called Prahasiteśvara. ${ }^{44}$ Referring to the patron deity of the king, the name of this linga also repeats that of another significant linga from the Indic world, installed at the capital of Pātaliputra. ${ }^{45}$ Iśānavarman or his advisors must have had this potent example of the merging of political and religious power in mind when installing Śiva in their capital. The record of Prahasiteśvara's installation, along with images of other deities and forms of Siva, was placed prominently in the eastern gateway of the enclosing wall of the temple complex designated the "S-group" by scholars. The western gateway contains another significant inscription, inventoried as K. $441,{ }^{46}$ but rather than praising religious foundations and deities enshrined within the city of İsānapura, this epigraph refers to Lingaparvata and the sacred landscape surrounding it (Figure 4). The function of this inscription within the larger epigraphic and iconographic program of the site remains obscure-Cœdès calls it 'enigmatic.' Composed in the

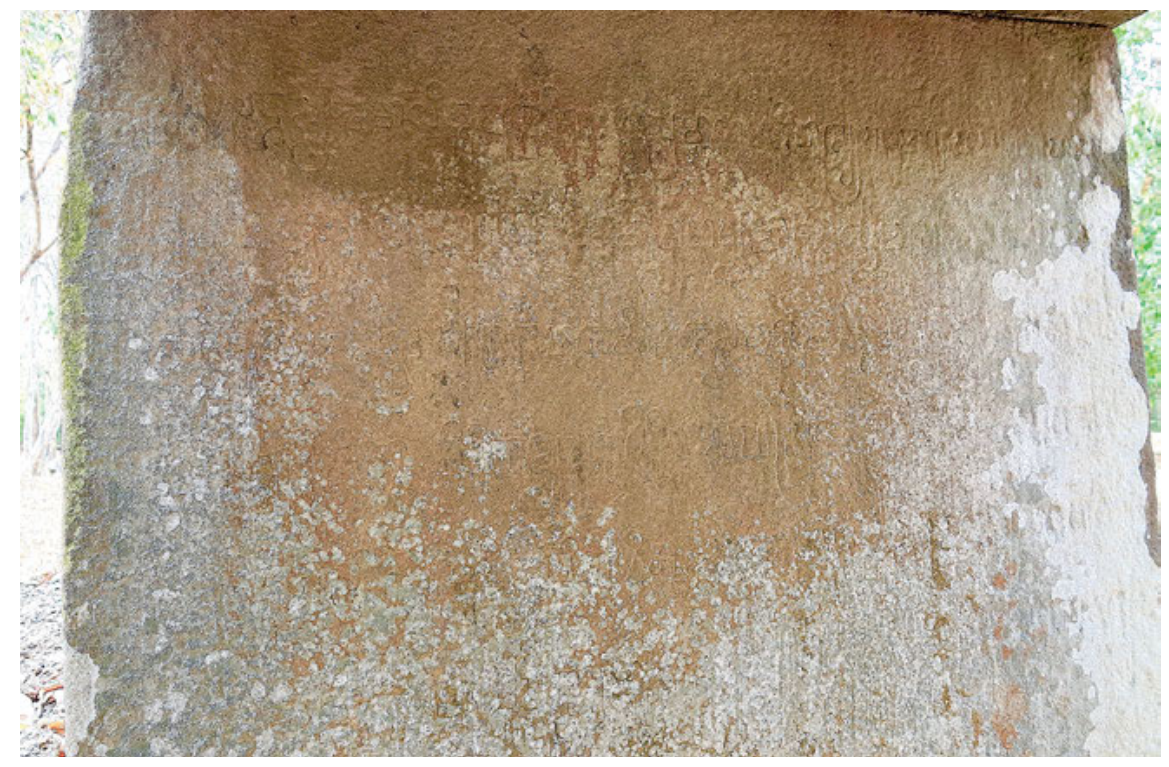

Figure 4: K. 441 in the western doorframe at Îsānapura (author photo).

44 Cœdès, Inscriptions du Cambodge 4, 5-11.

45 Bisschop, Sects and Centers, 36-37.

46 Codès, Inscriptions du Cambodge 4, 14-17. 
first person, a rarity in royal epigraphic writings, the speaker is matter-of-fact in proclaiming his intention to provide an oral cartography of a sacred landscape.

lingādri[kūṭa]lingasya tathā lingapure gireh

pramānam abhidhāsye 'ham ārohapariṇāhatah // 1 //

I will explain the measure of the linga on the peak of Linga Mountain, likewise of the mountain at Linga City, in terms of circumference and height.

sārddhāx pañcadaśavyāmā lingam ārohato mitam

vyāmāx pañcāśad așțau ca parito parị̣āhatah // 2 //

In terms of height, the linga measures $15 v y \bar{a} m a s^{47}$ together with a half (i.e. 7.5);

In terms of circumference, it encompasses 50 and 8 vyāmas.

ā lingamūlād ā bhūmer girir ārohato mitah

dve sahasre ca viñsāni vyāmāḥ saptaśatāni ca // 3 //

From the ground up to the base of the linga, the mountain measures

$2,000+700+20$ vyāmas in height.

ārohatax parimito giriśākhyapure girị

sahasram ekadhanaṃ șadviníati saptaśatāni // 4 //

The mountain at Giriśa City measures $1,000+700+26+1$ in height.

nirjharāx puṇyasalilā munivịndaniṣevitāh

sadā tatrānukurvvanti trayas tripathagāminīm // 5 //

The three waterfalls there, with purifying waters that are attended by crowds of sages, constantly imitate the course of the three-streamed Gangā.

tadadriśrningasānoś ca māne vistāramānatạ̣

saṃkhyam dvāviñśati vyāmās trinśá āyamatax punah // 6 //

The summit of the peak of the mountain, in terms of its two dimensions, numbers 22 vyāmas in breadth and 30 vyāmas in length.

The tone of the communication is akin to the didactic registers of śāstra rather than the eulogistic tone of praśasti. The speaker begins by stating the intention to declare the dimensions of the linga on the peak of lingādri - a clear synonym of the Lingaparvata introduced in K. 365 - and proceeds to enumerate these dimensions in detail. This mountain is further specified as being located at Lingapura, which again suggests a larger settlement or administrative zone oriented around the sacred mountain. Following Cœdès and others, I understand

47 This measurement is explained in Cœdès’s edition of the inscription. 
K. 441 as referring to the sanctified landscape around Vat Phu. In addition, another mountain, clearly associated with Śiva, is mentioned from the same region, Girisa, that also appears to be the center of a settlement area or pura. ${ }^{48}$ As mentioned above, the inscription does not explicitly state the reason or motivation for its pronouncement or the prominent display of the inscription within the Prahasiteśvara temple complex. That said, I think some valuable information can be gleaned even obliquely. As in the case of K. 341 from Śivapāda, K. 441 invokes the venerable Lingaparvata in the context of establishing another, new site of Saiva political religion. It aims to participate in the sanctity of this locale, which, although located at a considerable distance, clearly looms large in the religious and political memory of the agents behind the creation of Iśānapura. Who might have been the agent (or agents) behind this proclamation? The first-person voice and direct unadorned style of address does not suggest a royal persona, but perhaps an administrator or religious specialist closely associated with the court. The reportage style could also suggest a kind of pilgrim's inscription, whereby an official visitor to Lingaparvata reports the details of the sacred landscape that he has learned. The tone and presentation of the information, however, indicate that this was not a recreational visit. The speaker displays a mastery over the information the measurements are not mere estimations but are presented with a mathematical precision. This display of comprehensive knowledge should be understood as an act of control or an exercise of power.

Bracketing off these essentially unresolvable questions, I hypothesize that the intent that motivated the creation and display of the inscription was participation. K. 441, like K. 341, records the acts of historical agents for whom the prestige and memory of Lingaparvata was a powerful force. K. 341 is perhaps more transparent in this by explicitly stating the desire of the ruler to emulate the acts of $p \bar{u} j \bar{a}$ performed at Lingapura and to identify a prominent mountain as the site of another svayambhu manifestation of Śiva. Îsānapura is, by contrast, located in a riverine plain rather than a mountain locale, and the golden linga of Prahasiteśvara is not homologized to any natural feature, but is named after the linga of the famed capital of Pātaliputra. Despite these significant differences, K. 441, displayed in the

48 The mention of Giriśa, as a mountain located near Lingaparvata, is also found in one of the 7th century inscriptions of the ruler Mahendravarman, K. 363, which records the installation of a linga on the mountain Giriśa. Here we can observe repeated the pattern of sanctifying mountains using Śaiva toponyms and the connection between these newly named mountains and political geography. See Auguste Barth, "Inscription sanscrite du Phou Lokhon (Laos)," Bulletin de l'Ecole française d'Extrême-Orient 3 (1903): 442-446. On the other Mahendravarman inscriptions in the region around Vat Phu see Lorrillard, "Inscriptions in Laos," 90. 
central temple complex, indicates a clear desire to affiliate the site with a locale of significant prestige and, in doing so, position Îsānapura within a developing network of politically prominent Śaiva sites.

\section{Sanctifying Lingaparvata: The Ascetic Ideal}

The concluding verses of K. 441 add to the ideational construction of the sanctified landscape around Lingaparvata through the introduction of new associations. The waterfalls that flow at the mountain are described as purifying and likened to the three-streamed Gañgā, invoking the holy river par excellence. ${ }^{49}$ New characters are also introduced in the form of the ascetics and religious specialists (muni) who perform worship of these holy waters. ${ }^{50}$ While there are a number of waterfalls that flow around the mountain, this inscription may refer to a particular feature of the immediate landscape of Lingaparvata - namely, a natural spring still celebrated today for its healing prosperities. The development of the temple complex at the base of the mountain suggests that it was, in fact, oriented around this water feature and excavations at the site have revealed hydrological systems for the collection and adduction of spring water, as well as small shrines and brick foundations around its two outlets ${ }^{51}$ (Figure 5). As reported by the French Archaeological Mission, the efforts to further sacralize the area around the spring began in in the pre-Angkorian period, when a brick platform and portico were constructed around the natural rock shelter that encloses the spring area. ${ }^{52}$

These built interventions designed to amplify the area around the spring are roughly contemporaneous with an inscribed stone stele from the second

49 The reference to the three streams recalls a foundational myth in the Saiva tradition first recorded in Mahābhārata 3.107-108. As a reward for Bhagiratha's penance, Śiva agrees to facilitate the Gangā's descent to earth in three streams.

50 I understand verses 5 and 6 of K. 441 as referring back to the primary subject of the inscription, Lingādri, rather than as a description of Giriśa Mountain. In addition, the poet states the intention to explain three sets of measurements in relation to Lingādri; these are provided in verses 2,3 , and 6 . This is a further indication that verse 6 should be read as a continuation of the subject introduced in verse 1 .

51 The spring continues to be a center of religious activity for local ritual specialists and healers as well as the Buddhist community, which now controls the site.

52 The publications of the archaeological team mention finds of pre-Angkorian sculpture, ritual objects, and a range of pottery and ceramic material that suggests the active use of the spring area much before the development of the architectural temple in the tenth to eleventh century. For these details and illustrations see Santoni, Hawixbrock, and Souksavatdy, "La Mission archéologique française et le Vat Phu." 


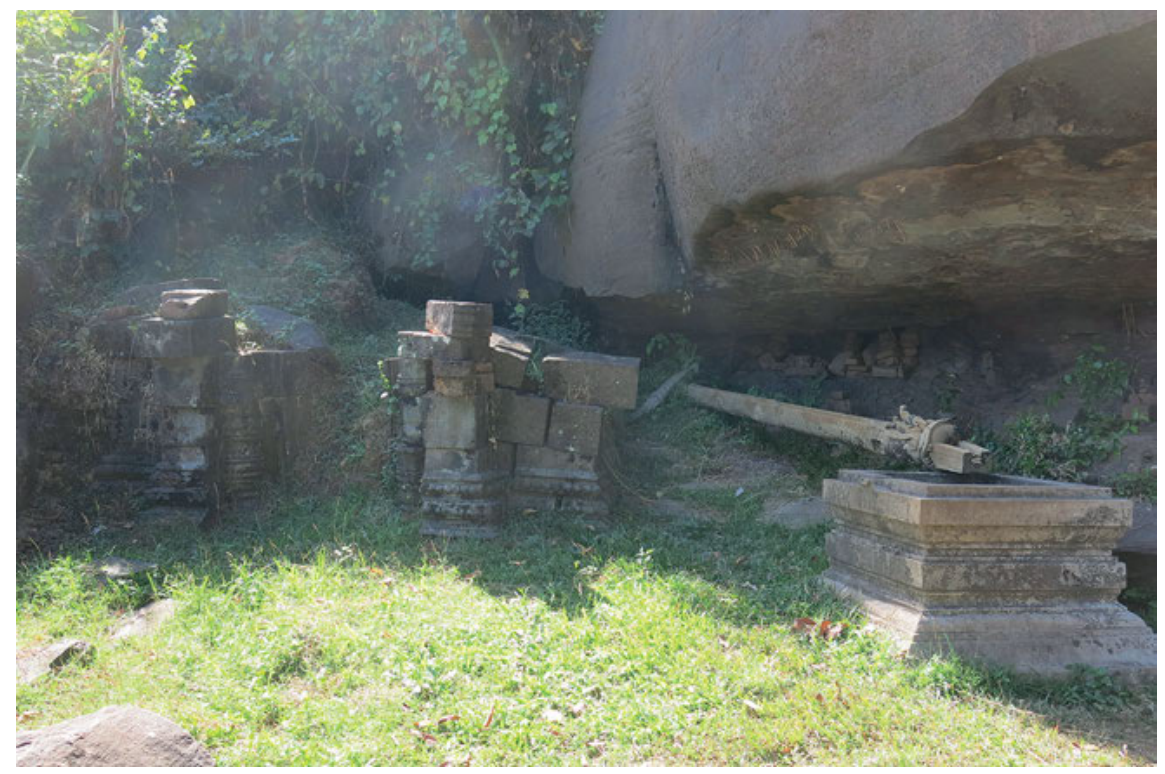

Figure 5: Remains of stone temple and water basin at source of sacred spring, Vat Phu Temple Complex (author photo).

half of the seventh century and issued in the time of the ruler Jayavarman I (K. 367), ${ }^{53}$ that was discovered buried under one of the terraces of the later temple complex (Figure 6). The purpose of the inscription was to ensure the sanctity of the area by aiding in its development as a space for ascetic practice. The opening lines of the five-verse record invoke Śiva as the deity who incinerated the god of Love, Kāma, when the latter dared to distract him from his asceticism by shooting him with the arrow of desire. ${ }^{54}$
śakrādir vvijito mayā mama śarā mogham gatā na kvacit so [']vaddhyaś ca madhus sakhā mama sadā vaśyañ ca nṛ̣āṃ manaḥ [/] ity evaṃ viganayya mānasabhavo vyaddhum gatas tatkșaṇaṃ yadroṣekșaṇajātabhasmanicayo rudreṇa jejīyatām [//1//]

Let Rudra (Śiva) be perpetually victorious! Whose furious gaze made the mind-born god (i.e. Love) but a heap of ashes with just a glance when Love took aim to shoot him with the

53 I use the edited text published by Salomon, Indian Epigraphy, 280-283. The translations are my own.

54 This scene is an innovation of Kalidāsa's fifth-century Kumārasambhava. This story and motif become part of the standard repertoire of Śaiva narrative icons in later Khmer art. 


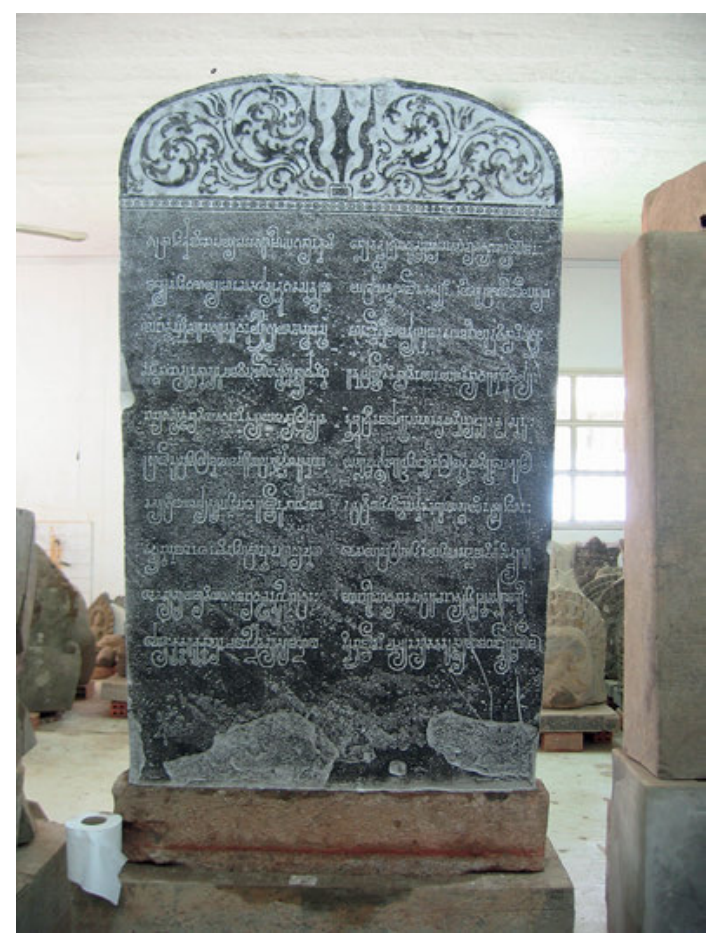

Figure 6: Inscribed stone stele of Jayavarman I (K. 367) (photo courtesy of Bertrand Porte, National Museum of Phnom Penh, Cambodia).

assumption, "I have conquered Indra and the other gods; my arrows never miss their target; my partner, Springtime, is invincible; and human hearts are eternally under my control.”

This sobering preamble sets the tone for the austerity measures that the inscription recommends. Following two verses in praise of Jayavarman, the second half of the record includes a series of interdictions aimed at circumscribing residential, agrarian, and recreational activities on Śri Lingaparvata. The articulation of these rules in the highly aestheticized language of Sanskrit, in metrical verse, and in stone, indicates their perceived necessity and gravity. I interpret this inscription as evidence of a premodern process of gentrification that displaced undesirable people and practices to make way for a new and pious elite. These efforts to amplify the sanctity of the land also introduced new modes of demarcating space that were not present in the earlier inscription of Devānika; these spatial categories include the Śaiva âsrama and the bhümaṇdala, about which I say more below.

In Verse 4, the inscription designates the venerable Lingaparvata as a place of non-violence where living creatures should not be harmed. 
tasya śrïjayavarmmabhūpater ājñ̄ānubhāvoda[yā]d

atra śrīmati lingaparvva[tava]re ye sthāyinah prānii[naḥ] [/*]

vaddhyantān na janena kenacid api prāptāparādhāh kadā devāya

pratipāditam yad iha taddhemādikam siddhyatu [// $\left.4 / /^{*}\right]$

As a consequence of the firm command of the Lord of the Earth, the illustrious Jayavarman, those living beings who dwell on the most excellent and illustrious Linga Mountain should not be harmed by any person even if, at times, they misbehave. May the offerings of gold and other things presented to the God here be efficacious!

devasyāsya yathābhilāṣagamanā gacchantu naivāśra[me] yānārohadhṛtātapatraracanābhyutksiptasaccāmaraih [/*] poșyāḥ kukkurakukkuțā na ca janair ddevasya bhūmaṇdaleșv ity ājñāoanipasya tasya bhavatu kṣmāyām alanghyā nụnām [// $\left.5 / /{ }^{*}\right]$ (Śārdūlavikrị̄ita)

In the sanctified area belonging to the God, people may not move about freely, they should not go around seated in palanquins, holding opened umbrellas, or while waving fancy yaktail fans overhead. Within the territories belonging to the God, people should not keep dogs nor raise chickens. This command of the king is inviolable for the people of the earth!

In verse 5 the term a asrama is introduced to refer to a sanctified area specific to the deity of the mountain. An âśrama does not necessarily imply the presence of a structural temple, although it could, what it more clearly suggests is a sanctified space of devotional activity and ascetic practice. The second new term introduced in Verse 5 is bhümandala. Again, the exact parameters of this designation are unclear, but I take it to refer more broadly to an area over which the deity had "juridical control," which could also include temple agrarian lands and other spaces used for the support of the deity and the people associated with his worship. The bhümandala, then, is a more expansive area that not only included, but also extended significantly beyond the sanctified area of the âsrama. The introduction of these terms assists in the demarcation of an ascetic landscape, yet it is important to note that the command of Jayavarman I designates this a political act as well. As Julia Estève and Dominique Soutif have shown, the of âsrama becomes a powerful tool for rulers that aided in the mapping of political boundaries as well as the sanctification of spaces within a polity. The ruler Yaśodharman I, known for the establishment of āśrama throughout the Khmer realm, provided for two of these establishments in the vicinity of Lingaparvata. ${ }^{55}$ Perhaps Jayavarman's civilizing

55 Julia Estève and Dominique Soutif, "Les Yaśodharāśrama, marqueurs d'empire et bornes sacrées Conformité et spécifi cité des stèles digraphiques khmères de la région de Vat Phu," Bulletin de l'École française d'Extrême-Orient, 97-98 (2010-2011): 331-355. The authors present two inscriptions from the area: K. 1005 and K. 362. The former is an unedited fragment that 
mission initiated a process of politically regulating the sanctified space that later rulers were compelled to expand.

Their precise parameters notwithstanding, the prohibitions put forth in verses 4 and 5 work to sanctify these spaces by cultivating a "reverential attitude." The explicit articulation of these rules also suggests that such behaviors were not intuitive, that is, that the space of the deity was not widely understood in this way or as requiring such behaviors and practices. These rules were intended, I would argue, to limit access to and use of the mountain for residential or recreational purposes. Hunting, for example, is not permitted. Given the sanctity of the âśrama, the inscription declares that this is a place where people should proceed on foot (i.e. not mounted on vehicles). Displays of material wealth or emblems of social prestige are also prohibited (i.e. people should travel without parasols or other insignia of royalty and emblems of social prestige like chowries). I interpret the ban on keeping chickens or dogs as a move to maintain ritual purity by restricting residential and perhaps also agrarian usage. As the composers of the inscription clearly express, these measures were made to ensure the efficacy of devotional and donative practices at the site.

Much of this ceremonious language would have fallen on deaf ears, however, since Sanskrit poetry was inaccessible to the majority of the population. The ruler (or the religious specialists or ascetics who commissioned the inscription) certainly would have had to employ people to communicate and enforce these admonitions. This linguistic distance is another expression of social disparity that served to further amplify the distinction between the sanctified space and the quotidian landscape.

I think we may also read a visual gesture to the transformation of the mountain into a sanctified Saiva space in the decorative accolade of the stele. The crowning point of the stone has been broken, but it would have had a pointed shape that recalled the peak of a mountain. This "mountain space" is filled with stylized swirls of lush foliage, at the center of which stands the trident - the weapon emblematic of Śiva - set upon a small pedestal. The curvilinear design of the trident's three prongs blends easily into the foliage, which serves to naturalize

mentions the deity Bhadreśvara, which becomes the official name of the Siva enshrined at Vat Phu. The second was recovered from a temple complex on the opposite side of the Mekong known as Huei Tomo and refers to the deity Rudrānī. On this temple and its relationship with Lingaparvata, see Oscar Nalesini, "The Sanctuary of Huei Thamo, and the Historical Problems Raised by its Survey," in Southeast Asian Archaeology 1998: Proceedings of the 7th Conference of the European Association of Southeast Asian Archaeologists, W. Lobo \& S. Reinemann, eds. (Hull, Centre for Southeast Asian Studies and Staatliche Museen zu Berlin, 2000), 123-138. 
its presence by suggesting that the imposition of Siva, though subtly menacing, is intrinsic to the mountain itself.

\subsection{Ascetics and the Mountain Caves}

This theme or ideal of renunciation was definitive of the architectural space that developed around Lingaparvata - images of long-haired, bearded ascetics, their knees bound in a meditational posture, appear throughout the temple complex and their figures adorn the bases of numerous columns, where they offer support to the crowning lintels that feature figures of royalty brandishing weapons: an architectural metaphor for the reciprocal socio-political relationship between ruler and religious specialist. Note the small mandapas that frame the ascetics in the pillar images. Remains of collapsed stone cellas, perhaps intended as meditational cells or dwellings for religious specialists, are preserved in the forested area of the mountain behind the temple complex (Figures 7 and 8).

In addition to constructed cells, ascetics also developed the natural caves near the spring. Slightly later than the record of Jayavarman, cave inscriptions K. 723 and K. 724 attest to the development of the âsrama as the abode of ascetics (Figure 9). This example, edited and dated paleographically to the late eighth/early ninth century by Dominic Goodall, is engraved on the overhang of a natural cave on the northeast slope of the mountain (Figure 10). ${ }^{56}$

(1) samādhaye sarvvatapodhanāṇā(2)ṃ

iyam guhā vaktraguheti nāmnā

(3) sā nirmmitā vaktraśivena śaktyā

(4) vibhāti bhaddreśvaraśailapārśve //

(5) kaṃ to chdyās guhā kaṃ ti rụ̣ pnāñ doṣa

This cave, named "Vaktra's Cave," which was prepared with great effort by Vaktraśiva as a sanctuary for all of the ascetics, shines forth from the side of the Bhadreśvara Mountain. [Old Khmer] Don’t obstruct the cave! Don't damage the partition! (It would be) a fault.

56 Dominic Goodall, “On K. 1049, A Tenth-Century Cave Inscription from Battambang, and the Sectarian Obedience of Saiva Ascetics of Non-Royal Cave-Inscriptions in Cambodia," UDAYA Journal of Khmer Studies 13 (2015): 3-34. Goodall's study presents a number of ascetic inscriptions and a revised edition of K. 723 and K. 724 (discussed on pp. 21-22), which I have reproduced in the quoted passage. 


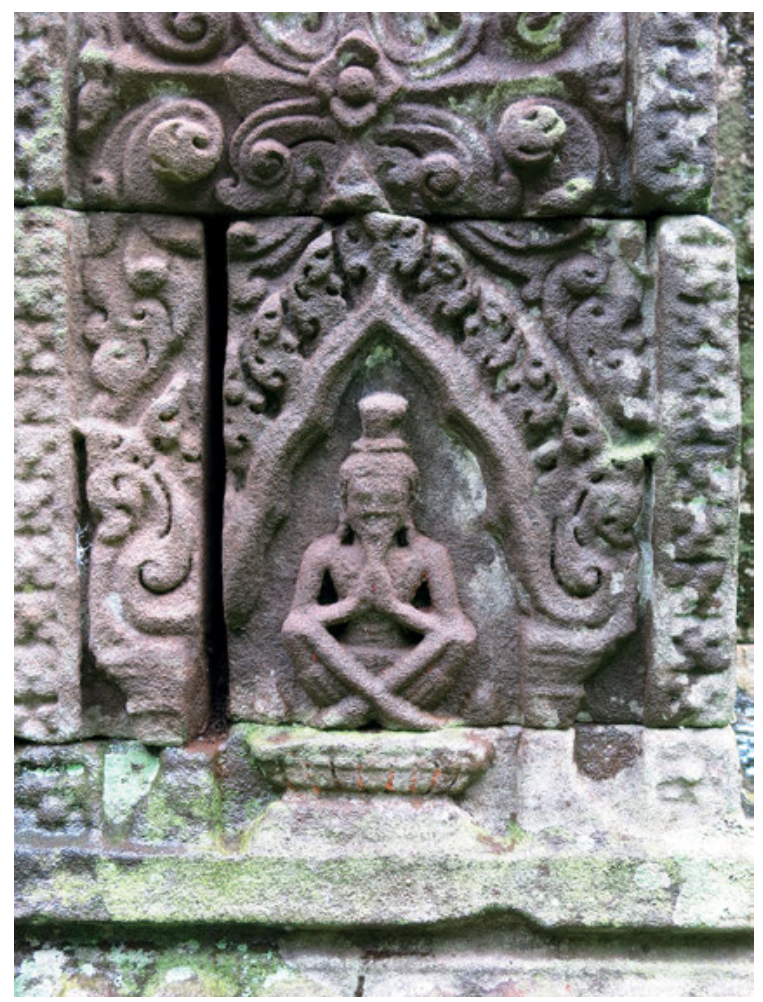

Figure 7: Brahmanical ascetic sculpted on pillar base, Vat Phu Temple Complex (author photo).

kam pi tve gāra le guhā

[Old Khmer] Don't use the cave as a dwelling!

This cave inscription introduces an individual with a name ending in -siva, a characteristic initiation name given to religious specialists of the Śaiva Siddhānta tradition. ${ }^{57}$ Vaktraśiva invests in the preparation of a cave as a space available to all ascetics. Since the cave in which the inscription was engraved is a natural rather than a man-made excavation, Vaktraśiva's work of preparing it likely involved augmenting the natural feature, cleaning the surrounding area of overgrowth, building around the enclosure, and ensuring that those using it respected its transformed state as a sanctuary or place for meditation (samādhi). This was

57 Goodall discusses this initiation name and explains that the prefix, Vaktra-, would have been ritually chosen by the initiate's guru, and that the -śiva suffix was a common marker of Saiddhāntika affiliation. See Goodall, “On K. 1049,” 21-22. 


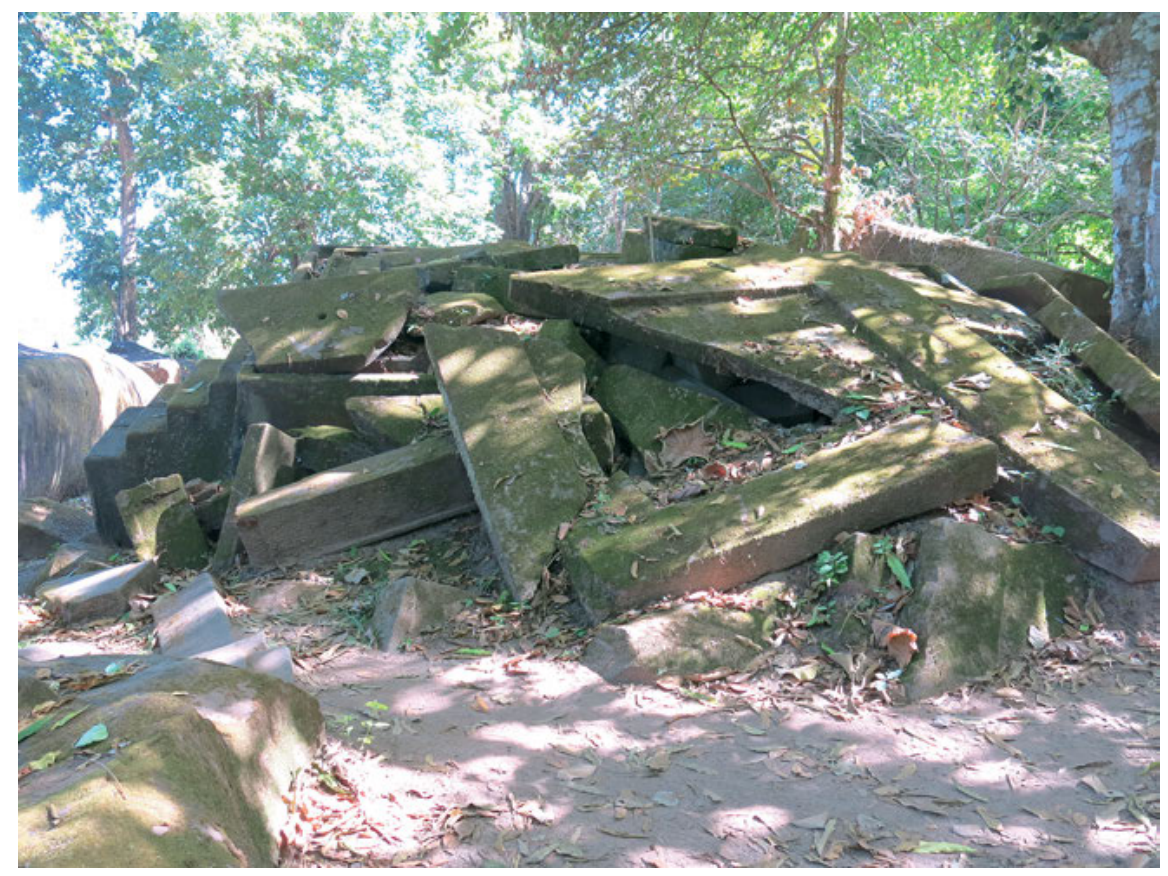

Figure 8: Collapsed stone cella, Vat Phu Temple Complex (author photo).

apparently not an easy task; the inclusion of śaktyā suggests something achieved with effort or hard work. The additional prohibitions in Khmer that direct the visitor to maintain these efforts and respect its sanctity by refraining from using the cave as a dwelling echo the behavioral changes commanded in Jayavarman's inscription. And while there is not explicit mention of a ruler in the epigraph, Vaktrassiva's renovation of the territory of the deity was likely supported by those in power. His transformation of the natural cave into a space for Saiva ascetics certainly seems to fit within the purview of Jayavarman's efforts to amplify the sanctity of the landscape through the imposition of Brahmanical Hinduism.

Vaktrassiva's inscription also introduces a significant new detail: the mountain is no longer referred to as Lingaparvata or as the generic “deva” of Jayavarman's record. We are now introduced to the mountain known as Bhadreśvara. The introduction of the name Bhadreśvara (the "Prosperous Lord") identifies a specific deity and does so using the suffix -iśvara commonly applied to lingas ritually installed for worship in temples. In this case, however, the "personal name" refers uniquely to the mountain itself, the svayambhu manifestation of the Lord Śiva.

I hypothesize that the presence and activities of the religious specialists occasioned this important change in the nomenclature and way of envisioning the 


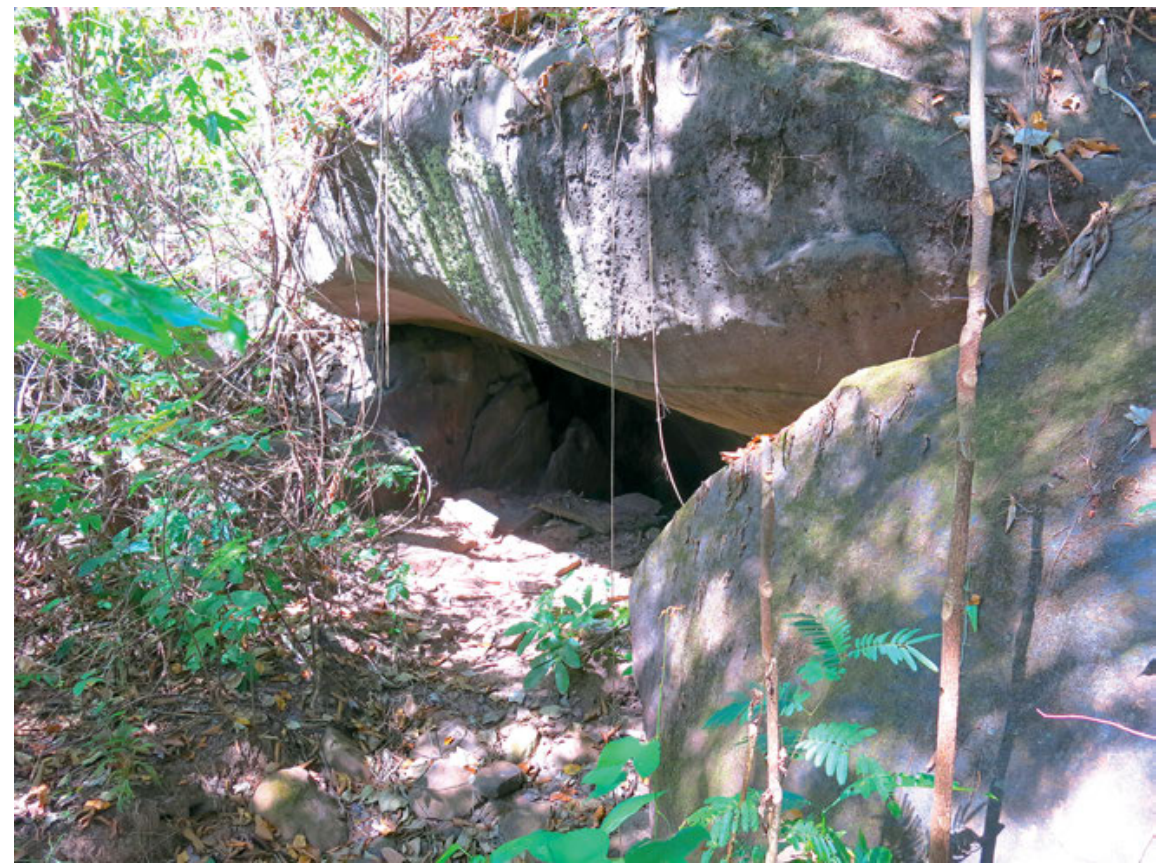

Figure 9: Site of K. 723 and K. 724 cave inscriptions (author photo).

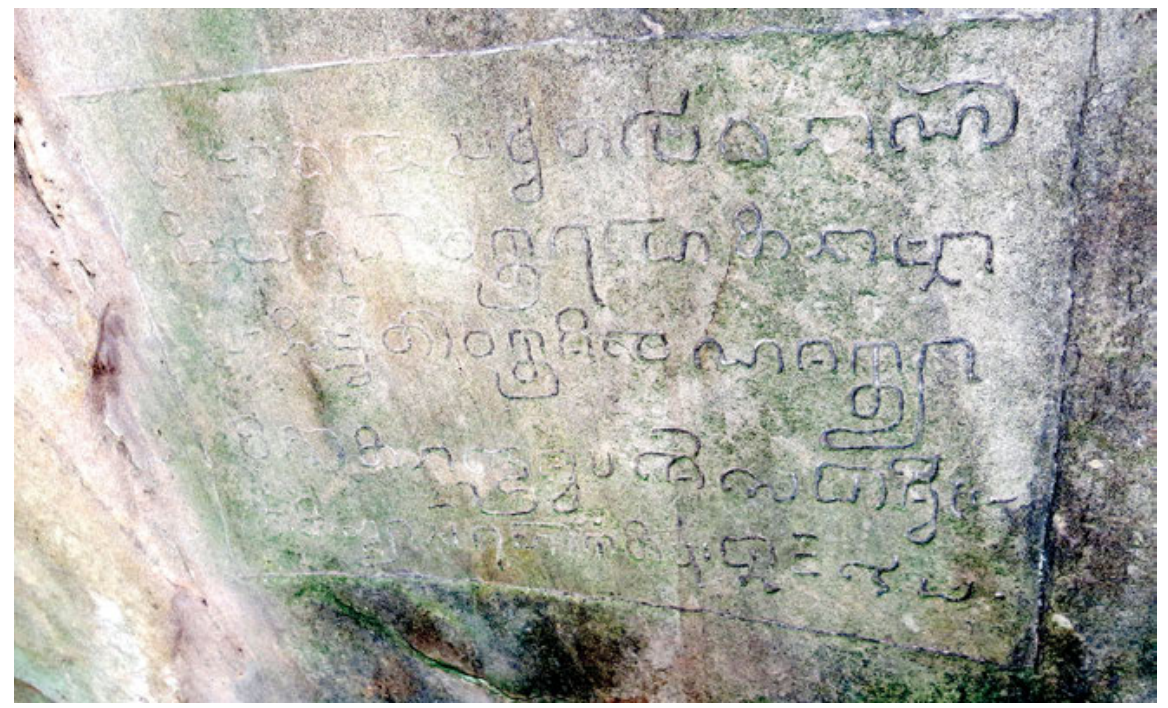

Figure 10: K. 723 on cave overhang (author photo). 
deity. The Śaiva Siddhanta teachers also carried with them specific modes of envisioning and representing the anthropomorphic Siva in iconography, in particular, the five-headed Sadāśiva - a distinct icon specific to these Śaiva practitioners, for whom each head (representative of an aspect of the deity) corresponded to one of their five Brahma mantras. Considering this Śaiva Siddhānta influence helps to contextualize and analyze one of the most central icons at the site, which can be dated to approximately the same period as the cave inscriptions: a bas-relief carving on a large boulder representing Śiva flanked by the deities Brahmā and Viṣnu (Figure 11). Previous studies have identified the sculpture as a trimūrti - i.e., a representation of the three primary male deities of the Hindu pantheon in which each represents a distinct, yet equal and interconnected, phase of the cosmological process. $^{58}$ This description is not accurate; the image communicates the supremacy of Śiva. Brahmā and Viṣnu occupy subordinate positions in the composition,

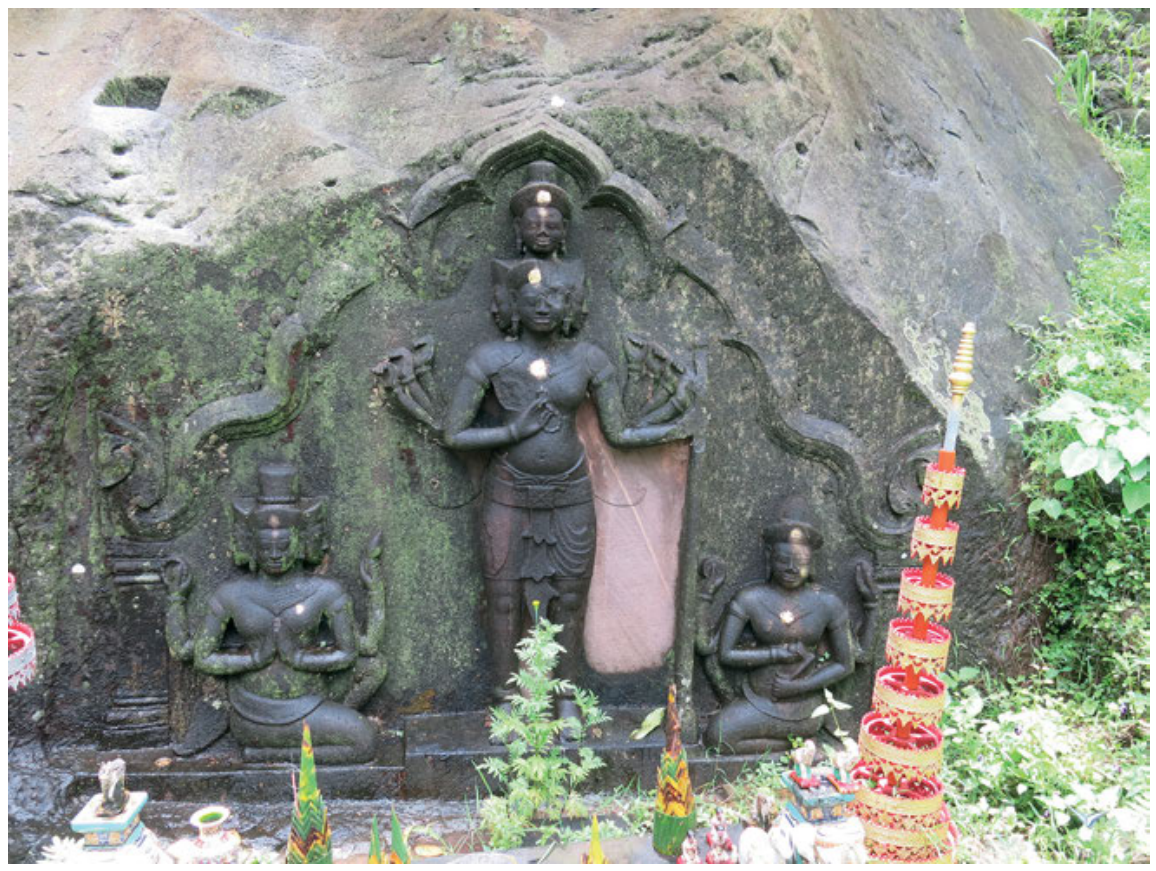

Figure 11: Relief carving of Bhadreśvara flanked by Vișṇu and Śiva on natural boulder, Vat Phu Temple Complex (author photo).

58 The image is referred to as trimūrti in Jacques, The Khmer Empire, 74 and Santoni, Hawixbrock, and Souksavatdy, "La Mission archéologique française et le Vat Phu,” 8. 
flanking the central deity and bowed in gestures of reverence. This is not a representation of three equally powerful gods, but rather, an icon demonstrating the victory of Śiva in his full five-headed and ten-armed glory.

I interpret this image as a distinctive representation of the lingodbhava ("Manifestation of the Linga") myth, a foundational narrative in which Siva manifests himself as a fiery linga of light. Brahmā and Viṣnu are challenged to find the beginning and end, respectively, but they fail and admit the supremacy of Śiva. Śiva then emerges in anthropomorphic form from the linga and Brahmā and Viṣnu worship him. Icons that represent this narrative typically depict the moment of emergence (i.e., the icons show both the linga and the anthropomorphic form, as is common in South Indian images of the same period). In the image from Lingaparvata, the figure of Siva emerges from a natural boulder in the mountain landscape. By representing the manifestation of Siva as Bhadreśvara, the artists made a bold theological statement in an iconographic style characteristic of the Śaiva Siddhānta, emerging from Lingaparvata itself: the "old god" of the local tradition was now fully transformed into the Prosperous Lord Siva of the Hindu tradition.

\section{The "Prosperous Lord" in the Land of the Khmer}

Pictures of the rock-cut image of Siva published in the archeological mission's reports reveal a brick terraced platform surrounding the boulder that was accessed via a small staircase. This brick foundation provided a space for ritual worship and may have been covered by a mandapa, conforming with the characteristic structure of the earliest Southeast Asian temples. ${ }^{59}$ The excavation also revealed the foundations of a long, pillared hall and a wall, contemporaneous with this brick platform, that extended between the rocky outcrop with the Siva icon to another large boulder to the south. ${ }^{60}$ This wall blocked the eastern approach to the natural spring. On the south side, a retaining wall was built between the rock face of the mountain and a large boulder. Large boulders blocked the approach from the north. The construction of these walls and

59 Parul Pandya Dhar, "Monuments, Motifs, Myths: Architecture and Its Transformations in Early India and Southeast Asia," in Cultural and Civilisational Links between India and Southeast Asia: Historical and Contemporary Dimensions, ed. Shyam Saran (New Delhi: Palgrave MacMillan, 2018), 325-344.

60 See the site diagrams provided in Santoni, Hawixbrock, and Souksavatdy, "La Mission archéologique française et le Vat Phu.” 
porticos directed access to the spring via one primary route - a long straight hall. These architectural features orchestrated movement to the spring and through the site and serve as a further indication of its centrality and sanctity to those designing the space.

The enclosing of the spring area was followed by the construction of a stone temple (likely completed around the eleventh century) built atop the foundations of a pre-Angkorian structure. The cult object of this later temple has been replaced by images of the Buddha, so we can only hypothesize as to the form of the deity it housed: perhaps an icon of Bhadreśvara or a linga fashioned from a piece of stone from the mountain, a practice attested in later Khmer inscriptions (see below). The temple received water from the spring via an underground aqueduct that channeled the flow of water to the back of the central shrine, where it could be used for the lustration of the cult image. The fashioning of the aqueduct is yet another example of the ways in which the design of the site was predicated on the manipulation of this landscape for political purposes. No longer part of a public space that could be accessed via multiple paths and for various reasons, the architecture silences that multivocality by showing that the flow of water serves a sole purpose: to bathe the Lord Śiva.

The area surrounding the shrine was further developed on an axis, ${ }^{61}$ from the flat surrounding plain to the base of the mountain through a prolonged ascent consisting of five terraced levels. The visitor to the site first encounters three vast water tanks (only two of which still hold water) and proceeds along a processional path lined by a stone balustrade and flanked by two smaller water tanks. The surrounding water mirrors the mountain in the distance, creating a reflection that serves to create an experience of interiority, as if one is actually venturing inside the mountain. The collection of water served the practical purpose of storage for the dry season, but this demonstration of control over natural resources is also a potent symbol of power. The water furthermore gestures to religious and ritual concerns surrounding purification and serves as a visual lustration of the linga mountain through landscape design. The processional path regulates access to the temple and the spring and effectively eliminates alternative approaches or informal routes (i.e. those paths often referred to as "desire lines") by submerging them in water. The imposing administrative buildings that line the processional path also serve to control access and limit spaces for participation (Figures 12, 13, and 14).

61 A feature of landscape design that Paul Wheatly has termed the "Axis of Power": see Nagara and Commander: Origins of the Southeast Asian Urban Traditions. (Chicago: University of Chicago, Dept. of Geography, 1983). 


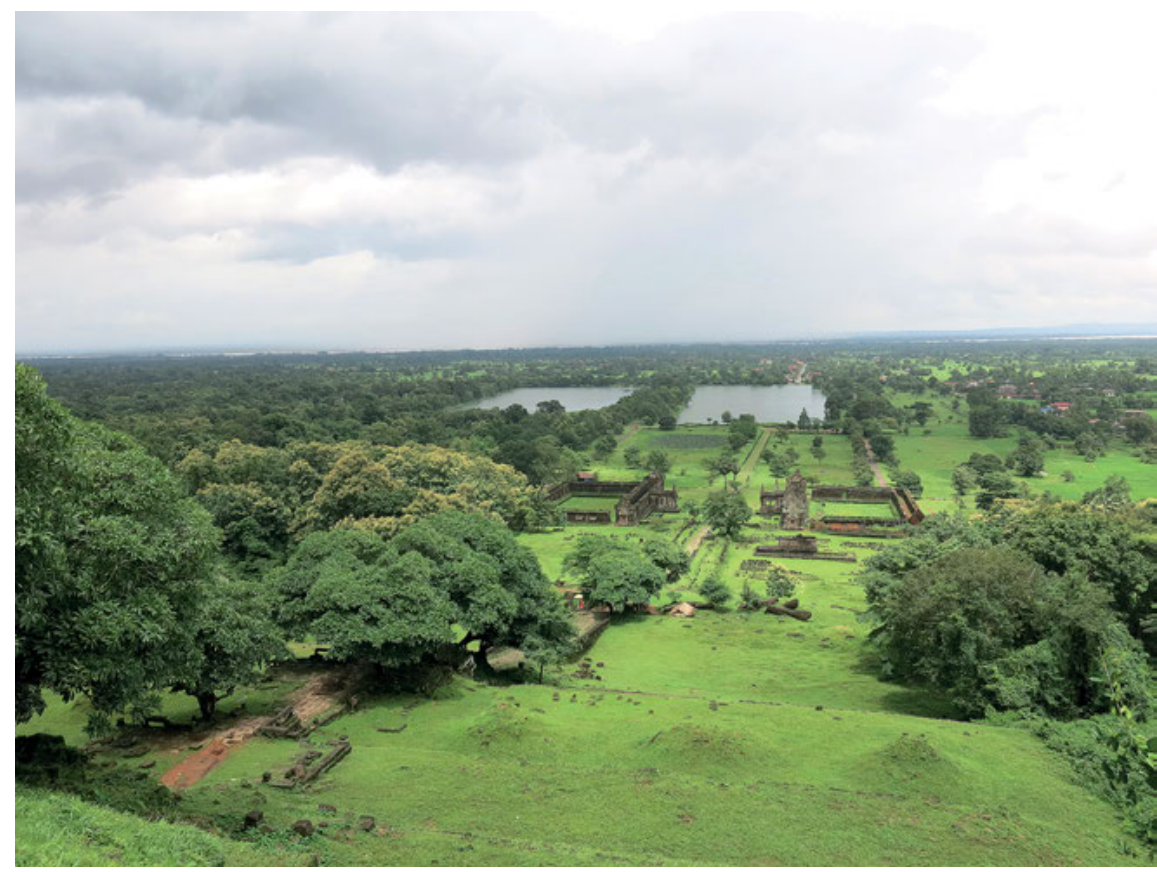

Figure 12: View of ascent to central shrine from upper terraced level, Vat Phu Temple Complex (author photo).

The aspirations to mastery expressed in the built landscape are echoed in another monumental Sanskrit inscription - a four-sided stele - discovered buried beside the entrance to one of the administrative buildings in the course of renovations at the site in 2013 (K. 1320). ${ }^{62}$ This tenth century record, edited and translated by Dominic Goodall and Claude Jacques, provides important evidence regarding the development of the mountain and the surrounding area as a zone of political control under Îsānavarman II and corresponds to the Angkorianperiod temple landscape that survives today. A primary purpose of the inscription is to record taxes in the form of goods, objects, and animals to the deity Bhadreśvara, designated as the Śiva here in this place (iha, atra).

62 Dominic Goodall, "Sanskrit Text and Translation of K. 1320, a Tenth-Century Edict of the Khmer King İsānavarman II About Annual Taxes to be Paid by Lingapura,” Bulletin de l'École française d'Extrême-Orient 103 (2014): 1-25. This article is based on an earlier edition and French translation of this inscription. See Dominic Goodall and Claude Jacques, "Stèle inscrite d’Îsānavarman II à Vat Phu: K. 1320,” Aséanie 33 (2014): 395-454. 


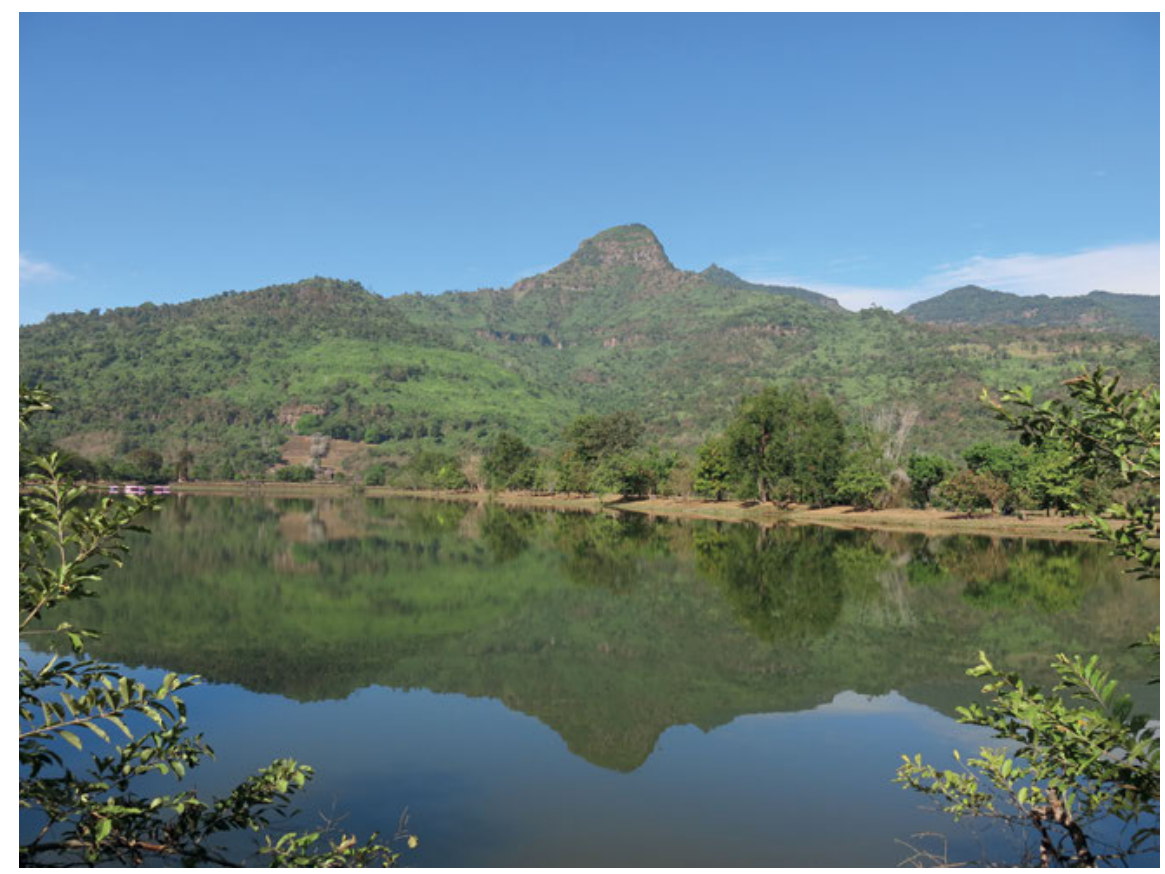

Figure 13: Reflection of Lingaparvata in one of the water tanks framing the processional path, Vat Phu Temple Complex (author photo).

\section{$\mathrm{V}(7)$ \\ pāyād apāraduritād iha śan்karaś śrỉbhadreśvaro bhuvanabhadrakaraś ciram vaḥ (8) yasyānghrinürajarajo 'vajayad rajāmsi tejāmsi tejayati bhaktibhṛt(ā)m adabhram //}

May the Śiva of this place, Sri Bhadreśvara (the "Prosperous Lord"), long protect you from endless want, he who effects prosperity (bhadra) in the world, the dust of whose lotus feet conquers impurities [and] intensely empowers the energies of the upholders of devotion/of those who support his worship.

$\mathrm{V}(60)$

(39) sa kamvujendro nijarājyaśāke jitān nṛpād dāyam upājahāra (40)

jitas tu bhaktyātra hare 'nuvarșalabhyam karam lingapurād vyatārīt //

In the era of his sovereignty, The Khmer Lord was offered gifts from conquered prince(s); but, since he was himself conquered by devotion, he donated the taxes acquired each year from Linga City to the Siva of this place.

The Lingapura administrative zone provides the goods donated in honor and support of the deity. For this deity is not only an object of veneration, but an independent juridical personality capable of owning property and commanding 


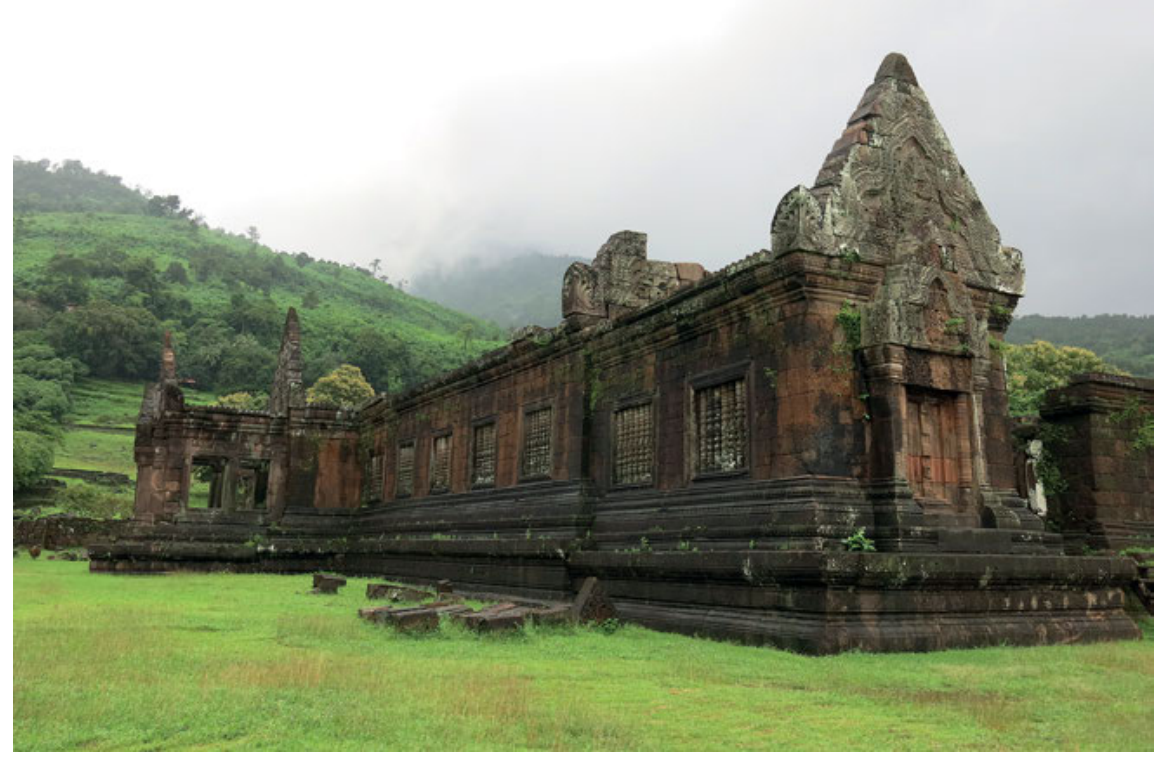

Figure 14: Administrative buildings lining processional path, Vat Phu Temple complex (author photo).

his own micro-economy: for example, in verse 92 the servants and slaves of the deity and those who live in in his āśramas are exempt from doing labor for the king and from paying taxes to government officials. ${ }^{63}$ This list of donated items is extensive, so I mention only a few highlights: 10 elephants, 12,000 peacock tail feathers, 100 parakeets, and 200 monitor lizards; fragrant woods, spices, resins, and herbs from the surrounding mountains; agrarian surplus, like paddy, millet, and mung beans from the cultivated lowland areas; and gold and other precious materials sourced from the Mekong River. The donative and economic realia of epigraphs are typically understood as practical or administrative, but the list given here is also ideological since it is a textual performance of the king's control of the landscape. This comprehensive list shows the ruler's ability

63 ye kiṅkarā lokatamonudaś śrībhadreśvarasyāpi tadāśramāṇām (34) te rājakāryyeșu na yojanìyā na dāpyadāyā vișayādhipādyaiḥ // 
to mobilize resources from every geographic zone under his rule and to make those resources available to the deity as surplus.

\section{Conclusions - Moving Mountains}

As the center of power in the land of the Khmer shifted to the south, the rulers colonized new mountains and claimed new landscapes in the name of Bhadreśvara, who was no longer tied exclusively to Lingaparvata, but elevated to the status of a state deity presiding over the political landscape in its entirety. ${ }^{64}$ Despite this geographic expansion, the Khmer rulers also actively maintained ties to the original sacred geography through donative practices, and the maintenance of infrastructure, such as royal roads that linked the site with the greater Angkorian landscape. ${ }^{65}$ The presence of a remarkable bronze image of Sadāsiva, the quintessential Saiddhāntika deity, from the region bears striking resemblance to the Bhadreśvara relief at Lingaparvata and could suggest that portable images of the mountain deity were also in circulation (Figure 15). Through these various links, a religious tradition so thoroughly fixed in the regional landscape and the mountain became portable and was used as a tool to anchor a transregional political formation.

The divinization of natural landscape features is certainly not unique to the Khmer realm or to Hinduism, nor is the connection between the God Siva and mountains an unexamined topic. What is perhaps insufficiently understood and theorized are the ways in which the spatial and material practices articulated in and through the worship of Siva were adapted by those aspiring to power. Though far from exhaustive, the study presented here has shown how significant landscape features reimagined as svyambhu manifestations of Siva have served as a source of empowerment for rulers. Rather than passive ground waiting to be vivified by human actions, the inscriptions and sites surveyed above indicate that control over landscape functioned as an integral part of a ruler's political repertoire. Moreover, situating the epigraphic sources in their physical and material contexts reveals that recourse to the aesthetic power of

64 The preeminence of Bhadeśvara and his elevation to state deity in the Angkorian period is discussed in Sanderson, “The Śaiva Religion," 409-421.

65 A number of inscriptions from the eleventh to the thirteenth centuries record donations of prestige goods by rulers and religious specialists in honor of Bhadreśvara and Lingaparvata: for example, K. 136, K. 418, and K. 963. 


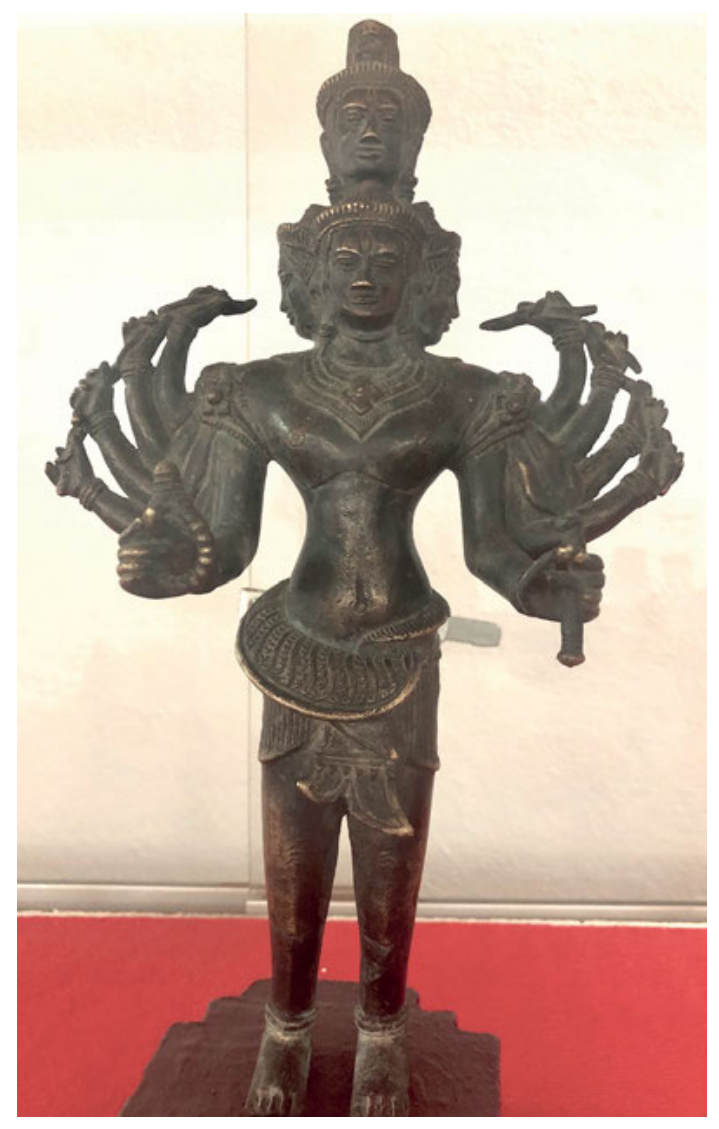

Figure 15: Bronze Sadāśiva image (Bhadreśvara?), c. $12^{\text {th }}-13^{\text {th }}$ century, Champasak Provincial Museum, Pakse (author photo).

Sanskrit or the cultural cache of Brahmanical forms of knowledge is insufficient to explain the widespread adoption of Hindu deities and ritual practices. Rather, as exemplified in the case of Lingaparvata, conceptions of and claims to political authority were conditioned by understandings of the power of place that preceded the introduction of Siva or other deities of the Indic pantheon. Considering landscape as a primary source highlights these connections and permits a contextualized history of Khmer political geography that is seen as shaped equally by indigenous conceptions of empowerment, Sanskrit-inflected models of sovereignty, and material strategies for manifesting dominance. 
Acknowledgements: I am grateful for the generous support of the American Council of Learned Societies (ACLS), the Getty Foundation, and the European Research Council (ERC) Synergy Project 609823, which made my research in Southeast Asia possible. I owe a special thanks to the scholars and staff at the World Heritage Office and site museum at Vat Phu in Laos for facilitating my fieldwork, and to David Bazin for his valuable guidance and for generously sharing his knowledge of the site and the surrounding area. I would also like to thank the conference participants for a stimulating event that raised many questions that I am still considering.

\section{Bibliography}

Bakker, Hans. "The Footprints of the Lord." In Devotion Divine: Bhakti Traditions from the Regions of India, Studies in Honor of Charlotte Vaudeville, edited by Diana L. Eck \& François Mallinson, 19-37. Groningen: Egbert Forsten/EFEO Paris, 1991.

Barth, Auguste. “Inscription sanscrite du Phou Lokhon (Laos)." Bulletin de l'École française d'Extrême-Orient 3 (1903): 442-446.

Bisschop, Peter C. Early Śaivism and the Skandapurāna: Sects and Centers. Groningen: Egbert Forsten, 2006.

Cecil, Elizabeth A. Mapping the Pāśupata Landscape: Narrative, Place, and the Śaiva Imaginary in Early Medieval North India. Leiden: Brill, 2020.

Cœdès, George, ed. Inscriptions du Cambodge. 6 vols. Hanoi: École française d'Extrême-Orient, 1937-1966.

Cœdès, George. "Nouvelles données sur les origines du royaume khmèr: la stèle de Văt Luong Kău près de Văt P'hu." Bulletin de l'Ecole française d'Extrême-Orient 48, no. 1 (1956): 209-220.

Dhar, Parul Pandya. "Monuments, Motifs, Myths: Architecture and its Transformations in Early India and Southeast Asia." In Cultural and Civilisational Links between India and Southeast Asia: Historical and Contemporary Dimensions, edited by Shyam Saran, 325-344. New Delhi: Palgrave MacMillan, 2018.

Eck, Diana. Banaras: City of Light. New York: Columbia University Press, 1982.

Eck, Diana. “India's Tirthas: Crossings in Sacred Geography." History of Religions 20, no. 4 (1981): 323-344.

Estève, Julia and Dominique Soutif. “Les Yaśodharāśrama, marqueurs d'empire et bornes sacrées Conformité et spécifi cité des stèles digraphiques khmères de la région de Vat Phu." Bulletin de l'École française d'Extrême-Orient 97-98 (2010-2011): 331-355.

Estève, Julia. "Mapping the Sacred: Towards a Religious Geography of Ancient Cambodia through a Toponymic Atlas of Cambodian Inscriptions." In Writing for Eternity: A Survey of Epigraphy in Southeast Asia, edited by Daniel Perret, 87-108. Paris: EFEO, 2018.

Fleming, Benjamin J. "Mapping Sacred Geography in Medieval India: The Case of the Twelve Jyotirlingas." International Journal of Hindu Studies 13, no. 1 (2009): 51-81.

Forest, Alain. Le culte des génies protecteurs au Cambodge: Analyse et traduction d'un corpus de textes sur les neak ta. Paris: L'Harmattan, 1992. 
Goodall, Dominic. "On K. 1049, A Tenth-Century Cave Inscription from Battambang, and the Sectarian Obedience of Śaiva Ascetics of Non-Royal Cave-Inscriptions in Cambodia." UDAYA Journal of Khmer Studies 13 (2015): 3-34.

Goodall, Dominic. "Sanskrit Text and Translation of K. 1320, A Tenth-Century Edict of the Khmer King Îsānavarman II about Annual Taxes to Be Paid by Lingapura." Bulletin de l'École française d'Extrême-Orient 103 (2014): 1-25.

Goodall, Dominic and Jacques, Claude. "Stèle inscrite d'Î́sānavarman II à Vat Phu:

K. 1320," Aséanie 33 (2014): 395-454.

Graeber, David and Marshall Sahlins. On Kings. Chicago: University of Chicago Press, 2017.

Guy, John. "Shiva's Land: Brahmanical Sculpture in the Religious Landscape of Early

Southeast Asia," Orientations 45, no. 3 (2014): 50-57.

Guy, John. "Tamil Merchants and the Hindu-Buddhist Diaspora." In Early Interactions between

South and Southeast Asia. Reflections on Cross-Cultural Exchange, edited by Pierre-Yves Manguin, A. Mani, and Geoff Wade, 243-262. Singapore: ISEAS Publishing, 2011.

Jacques, Claude and Philippe Lafond. The Khmer Empire: Cities and Sanctuaries Fifth to Thirteenth Centuries. Bangkok: River Books, 2007.

Jacques, Claude. "The Kamrater Jagat in Ancient Cambodia." In Indus Valley to Mekong Delta: Explorations in Epigraphy, edited by Noboru Karashima, 269-286. Madras: New Era Publications, 1985.

Jacques, Claude. “Notes sur l'Inscription de la Stèle de Vat Luong Kau." Journal Asiatique 250, no. 2 (1962): 249-256.

Jacques, Claude. "Two notes on Vat Phou." Accessed May 1, 2020. https://www.vatphou-champassak.com/pdfs/Claude\%20Jacques\%20MEP.2017.07.14.pdf

Kielhorn, L. F. “Pahari Pillar Inscription of Yuvarājadeva II (861 CE).” Epigraphia Indica 9 (1907-1908): 248-56.

Lorrillard, Michel. "Research on the Inscriptions in Laos." In Writing for Eternity: A Survey of Epigraphy in Southeast Asia, edited by Daniel Perret, 87-108. Paris: EFEO, 2018.

Lorrillard, Michel. "Settlement and Spatial Planning around Wat Phu." Unpublished paper and slides presented at the 15th EurASEAA conference. Accessed April 1, 2019. https://www. academia.edu/13921342/EurASEAA_15_conference_Settlement_and_Spatial_Planning_ around_Wat_Phu.

Lorrillard, Michel. "Par-delà Vat Phu. Donées nouvel les sur l'expansion des espaces khmer at môn anciens au Laos." Bulletin de l'École française d'Extrême-Orient 97-98, (2010-2011): 205-270.

Lorrillard, Michel. "Pre-Angkorian Communities in the Middle Mekong Valley." In Before Siam: Essays in Art and Archaeology, edited by Nicolas Revire and Stephen A. Murphy, 186-215. Bangkok: River Books, 2014.

Lorrillard, Michel. "Du centre à la marge: Vat Phu dans les études sur l'espace khmer ancient." Bulletin de l'École française d'Extrême-Orient 97-98 (2010-2011): 187-204.

Miksic, John N. "Heterogenetic Cities in Premodern Southeast Asia." World Archaeology 32, no. 1 (2000): 106-120.

Murphy, Stephen A. and H. Leedom Lefferts. "Adoption of Buddhism and Brahmanism.” In The Routledge Handbook of Archaeology and Globalization, edited by Tamar Hodos, 768-789. London: Routledge, 2017.

Mus, Paul. “Cultes indiens et indigènes au Champa.” Bulletin de l'École française d'Extrême-Orient 33 (1933): 367-410. 
Nalesini, Oscar. "The Sanctuary of Huei Thamo, and the Historical Problems Raised by its Survey." In Southeast Asian Archaeology 1998: Proceedings of the 7th Conference of the European Association of Southeast Asian Archaeologists, edited by W. Lobo \& S. Reinemann, 123-138. Hull: Centre for Southeast Asian Studies and Staatliche Museen zu Berlin, 2000.

Pollock, Sheldon. The Language of the Gods in the World of Men: Sanskrit, Culture, and Power in Premodern India. Berkeley: University of California Press, 2006.

Sahai, Sachchidanand. Shivapada in Khmer Art: Rediscovering Angkor in the Footprints of Shiva. Bangkok: White Lotus, 2011.

Salomon, Richard. Indian Epigraphy: A Guide to the Study of Inscriptions in Sanskrit, Prakrit, and other Indo-Aryan Languages. New York: Oxford University Press, 1998.

Sanderson, Alexis. "Śaiva Religion Among the Khmers (Part 1)." Bulletin de l'École française d'Extrême-Orient 90-91 (2003): 349-462.

Santoni, Marielle, Christine Hawixbrock, “Laos. Fouilles et prospections dans la région de Vat Phu (province de Champassak, sud du Laos)." Bulletin de l'École française d'ExtrêmeOrient 85, no. 1 (1998): 387-405.

Santoni, Marille, Christine Hawixbrock, and Viengko Souksavatdy. "La Mission archéologique française et le Vat Phu: recherches sur un site exceptionnel du Laos." In Recherches nouvelles sur le Laos, edited by Y. Goudineau and M. Lorrillard, 81-111. Études Thématiques 18. Vientiane: EFEO, 2008.

Stark, Miriam. "Southeast Asian Urbanism: From Early City to Classical State." In The Cambridge World History. Vol. 3, Early Cities in Comparative Perspective, 4000 BCE-1200 $C E$, edited by Norman Yoffee, 74-93. Cambridge: Cambridge University Press, 2015.

Sukthankar, V. S., S. K. Belvalkar, and P. L. Vaidya, eds. The Mahābhārata for the First Time Critically Edited. Poona: Bhandarkar Oriental Research Institute, 1933.

Vickery, Michael. Society, Economics and Politics in Pre-Angkor Cambodia: The 7th-8th Centuries. Tokyo: The Centre for East Asian Cultural Studies for Unesco, The Toyo Bunko, 1998.

Wheatley, Paul. "Urban Genesis in Mainland Southeast Asia." In Early Southeast Asia: Essays in Archaeology, History, and Historical Geography, edited by R. B. Smith and W. Watson, 288-303. New York: Oxford University Press, 1979.

Wheatley, Paul. Nagara and Commander: Origins of the Southeast Asian Urban Traditions. Chicago: University of Chicago, Dept. of Geography, 1983.

Wolters, O.W. "A 'Hindu' Man of Prowess." In History, Culture, and Region in Southeast Asian Perspectives (rev. ed.), 226-228. Ithaca, NY: Cornell Southeast Asia Program Publications, 1999. 
